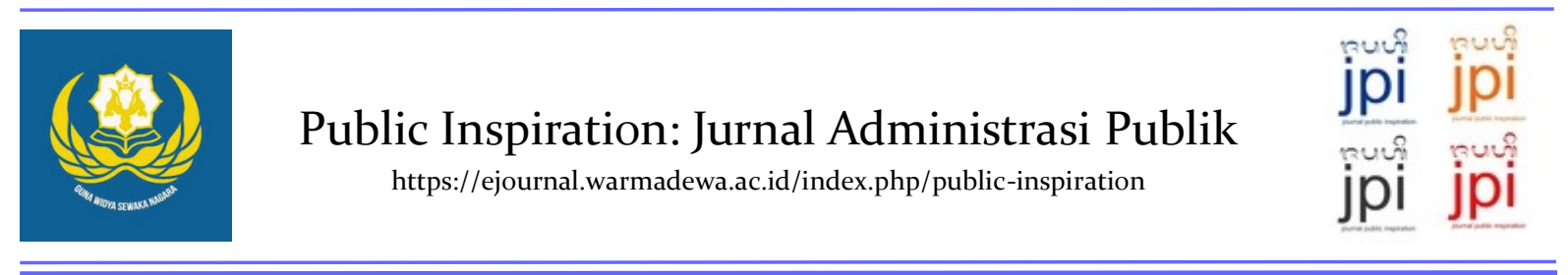

\title{
Pengaruh Penagihan Pajak dan Kepemilikan Nomor Pokok Wajib Pajak Terhadap Kesadaran Wajib Pajak dan Penerimaan Pajak di Kantor Pelayanan Pajak Pratama Gianyar
}

\author{
Tjokorda Gde Anggadhika Widya Pramana Putra \\ Undiknas Graduate School, Denpasar, Bali-Indonesia \\ Corespondence E-mail: anggadhikaı@gmail.com
}

How to Cite: Putra, T. G. A. W. P. (2021). Pengaruh Penagihan Pajak dan Kepemilikan Nomor Pokok Wajib Pajak Terhadap Kesadaran Wajib Pajak dan Penerimaan Pajak di Kantor Pelayanan Pajak Pratama Gianyar. Public Inspiration: Jurnal Administrasi Publik, 6(2): 116-141. DOI: https://doi.org/10.22225/pi.6.2.2021.116-141

\begin{abstract}
From 2014 to 2018 the number of taxpayers registered at the Gianyar KPP Pratama continued to grow. The largest growth occurred in 2016, which was $9.26 \%$ and the smallest growth in 2018 was $7.59 \%$. In terms of tax revenue, the highest increase in the realization of tax revenue growth at KPP Pratama Gianyar occurred in 2017, which was $39.06 \%$. In 2016, tax revenue growth decreased by 3.02 percent. This increase in revenue continued to occur in 2018, although the growth rate was not as high as 2017. This research motivation is to examine the role of mandatory ownership of NPWP, tax audit, collection of tax, and taxpayer awareness of tax revenue at KPP Pratama Gianyar. This is quantitative research, conducted by data analysis using SMARTPLS based on sample of taxpayers registered at KPP Pratama Gianyar. Results of the study at the KPP Pratama Giayar, concluded that direct tax collection actions have a positive and significant effect on increasing tax revenue. The obligation to have a NPWP directly has a positive and significant impact on the awareness of taxpayers. Direct tax revenues will be positively and significantly influenced by the awareness of taxpayers. With the mediated awareness of taxpayers, the effect of tax collection on tax revenues proved positive and significant, and obtain 1 (one) form of partial mediation. With the mediated awareness of taxpayers, the effect of NPWP ownership obligations on tax revenues is proven to be positive and significant, and obtain 1 (one) form of full mediation.
\end{abstract}

Keywords: Tax Collection; NPWP; Taxpayers Awareness; Tax Revenue

\section{Abstrak}

Dari Tahun 2014 sampai tahun 2018 jumlah WP yang terdaftar di KPP Pratama Gianyar terus bertumbuh. Pertumbuhan terbesar terjadi di tahun 2016, tercatat sebesar 9,26\% dan sedang kenaikan terkecil di tahun 2018 yaitu 7,59\%. Dari sisi penerimaan pajak, Realisasi peningkatan tertinggi penerimaan pajak di KPP Pratama Gianyar terjadi pada tahun 2017, yaitu bertumbuh sebesar 39,06 \%. Pertumbuhan pada periode 2016, penerimaan pajak menurun sebesar 3,02 persen. Peningkatan penerimaan pajak tetap terjadi di tahun 2018, meskipun tingkat pertumbuhannya tidak sebesar periode 2017. Motivasi dari penelitian ini yaitu menguji peran kewajiban kepemilikan NPWP, pemeriksaan pajak, penagihan pajak, dan kesadaran wajib pajak terhadap penerimaan pajak di KPP Pratama Gianyar. Jenis penelitian adalah penelitian kuantitatif dengan analisa data menggunakan SMART-PLS. Berdasarkan hasil penelitian di KPP Pratama Gianyar, dapat disimpulkan bahwa penagihan pajak secara langsung berpengaruh positif dan signifikan dalam meningkatkan penerimaan pajak. Kewajiban kepemilikan NPWP secara langsung berpengaruh positif dan signifikan dalam kesadaran wajib pajak. Penerimaan pajak secara langsung akan dipengaruhi secara positif dan signifikan oleh kesadaran wajib pajak. Dengan dimediasi Kesadaran wajib pajak, pengaruh penagihan pajak terhadap penerimaan pajak terbukti positif dan signifikan, dan mendapatkan 1 (satu) bentuk partial mediation. Dengan dimediasi kesadaran wajib pajak, pengaruh kewajiban kepemilikan NPWP terhadap penerimaan pajak terbukti positif 
dan signifikan, dan mendapatkan 1 (satu) bentuk full mediation.

Kata kunci: Penagihan Pajak; NPWP; Kesadaran Wajib Pajak; Penerimaan Pajak

\section{Pendahuluan}

Peranan pajak dalam membiayai pembangunan terlihat dari sumber penerimaan Anggaran Pendapatan dan Belanja Negara (APBN) tahun 2014-2018. Tahun 2014 sebesar $73 \%$, dari realisasi penerimaan negara, tahun 2015 terjadi peningkatan yang sangat tinggi menjadi sebesar $82 \%$ kemudian meningkat menjadi $83 \%$ di tahun 2016 . Tahun 2017 , total penerimaan negara bersumber dari penerimaan pajak menurun menjadi sebesar $81 \%$ dari, dan menurun lagi menjadi sebesar $78 \%$ pada tahun 2018 .

Dirjen pajak berusaha agar wajib pajak (selanjutnya disebut WP) secara sukarela membayar pajaknya. Dengan makin banyaknya Wajib Pajak memperoleh penghasilan, penerimaan negara melalui pajak akan meningkat. Kehilangan potensial penerimaan negara karena pemberlakuan kebijakan penghapusan fiskal dapat teratasi. Dalam upaya menaikan penerimaan pajak negara, berbagai upaya dilakukan, dengan melalui ekstensifikasi maupun intensifikasi penerimaan pajak. Ekstensifikasi adalah upaya menaikan penerimaan pajak dengan menaikan jumlah Wajib Pajak aktif. Sedangkan intensifikasi ditempuh dengan cara menaikan kesadaran Wajib Pajak, menaikan kualitas pelayanan untuk Wajib Pajak, pengawasan akan administratif perpajakan, pemeriksaan, penyidikan, penagihan, serta berbagai penegakan hukum. Penerimaan pajak yang berasal dari meningkatnya kepemilikan Nomor Pokok Wajib Pajak (selanjutnya disebut NPWP) berasal dari pembayaran pajak dapat dimonitor dan didapatkan dari setiap penyampaian SPT oleh WP yang memiliki NPWP.

KPP Pratama Gianyar merupakan KPP yang terdapat di Bali. Diakhir tahun 2018 KPP Pratama Gianyar tercatat memiliki 161.754 wajib pajak. Periode tahun 2014 - 2018, jumlah wajib pajak terdaftar pada KPP Pratama Gianyar mengalami pertumbuhan. Pertumbuhan terbesar didapatkan tahun 2016, yaitu sebesar 9,26\% dan pertumbuhan terkecil di tahun 2018 yaitu 7,59\%.

Kenaikan tertinggi realisasi peningkatan penerimaan pajak pada KPP Pratama Gianyar terdapat di tahun 2017, yaitu sebesar 39,06 persen. Pada tahun 2016, peningkatan penerimaan pajak menurun sebesar 3,02 persen. Di tahun berikutnya terjadi peningkatan yang signifikan. Peningkatan dari penerimaan tetap terjadi pada tahun 2018, meskipun peningkatan tidak sebesar tahun 2017. Terjadi penerimaan dan pertumbuhan pajak yang fluktuatif periode 2014-2018.

Pemungutan pajak menganut sistem self assessment. Dalam pembinaan, penelitian dan pengawasan terhadap pelaksanaan kewajiban perpajakan wajib pajak, Direktorat Jenderal Pajak dapat mengeluarkan ketetapan pajak. Ketetapan pajak ini termasuk komponen official assessment. Surat Ketetapan Pajak merupakan produk hukum yang muncul karena adanya pemeriksaan pajak yang berisikan penjelasan tentang dasar-dasar timbulnya koreksi pajak. besarnya sanksi dan pajak yang terutang (Sutrisno, 2016).

Kebijakan yang dilaksanakan untuk mengoptimalkan penerimaan pajak dilakukan dengan penagihan pajak yang lebih aktif kepada wajib pajak yang menunggak pembayaran pajaknya (Ginting, 2006). Penagihan pajak dilaksanakan karena masih banyak wajib pajak terdaftar yang belum melunasi hutang pajaknya, hingga diperlukan tindakan-tindakan penagihan dengan kekuatan hukum yang bersifat mengikat dan memaksa. Dengan persetujuan DPR RI, pemerintah mengeluarkan UU nomor 19 tahun 2000 tentang Penagihan Pajak dengan Surat Paksa. Berdasarkan UU nomor 19 tahun 2000, Penagihan pajak adalah serangkaian tindakan-tindakan dalam upaya membuat wajib pajak melunasi utang pajak dan biaya penagihan pajak dengan cara menegur atau memperingatkan. Kemudian melakukan penagihan seketika dan sekaligus memberitahukan surat paksa. Juga mengusulkan pencegahan, melaksanakan penyitaan, penyanderaan dan juga menjual barang yang telah 
disita.

Dalam upaya memaksimalkan penerimaan pajak, pemerintah mengeluarkan kebijakan -kebijakan untuk memancing kesadaran masyarakat mau membayar pajak. Tedapat beberapa faktor hal yang harus dikaji pemerintah sebelum membuat kebijakan sebagai pembuat kebijakan. Diantaranya faktor - faktor apa saja yang dapat mempengaruhi penerimaan pajak, diantaranya pemerintah, petugas pajak (fiskus) dan masyarakat yang sangat berperan penting untuk memaksimalkan penerimaan pajak

Untuk memaksimalkan penerimaan pajak melalui sistem self-assessment, selain dengan cara meningkatkan jumlah Wajib Pajak aktif. Pemerintah agar berusaha agar wajib pajak semakin sadar pentingnya membayar pajak bagi pembangunan nasional. Guna meningkatkan kesadaran membayar pajak, pemerintah melaksanakan kegiatan sosialisasi perpajakan yang bertujuan memberikan masyararakat tentang pemahaman mengenai perpajakan di Indonesia. Pemerintah juga menginformasikan bukti-bukti bahwa pembayaran pajak oleh masyarakat memang disalurkan bagi kepentingan masyarakat, dengan cara transparansi administrasi perpajakan. (Herryanto, 2013).

Tujuan dari penelitian ini adalah untuk menganilisis pengaruh kewajiban kepemilikan NPWP, pemeriksaan pajak, penagihan pajak, dan kesadaran wajib pajak terhadap penerimaan pajak.

Rumusan masalah sebagai berikut.

Bagaimanakah pengaruh penagihan pajak terhadap kesadaran WP di KPP Pratama Gianyar?

Bagaimanakah pengaruh kepemilikan NPWP terhadap kesadaran WP di KPP Pratama Gianyar?

Bagaimanakah kesadaran WP terhadap penerimaan pajak di KPP Pratama Gianyar?

Adakah pengaruh penagihan pajak terhadap penerimaan pajak melalui kesadaran WP di KPP Pratama Gianyar?

Adakah pengaruh kepemilikan NPWP terhadap penerimaan pajak melalui kesadaran WP di KPP Pratama Gianyar?

\section{Konsep dan Teori}

\section{Penagihan Pajak}

Dalam pasal 1 butir 9 UU Nomor 19 Tahun 2000, disebutkan penagihan pajak adalah serangkaian tindakan agar wajib pajak melunasi utang pajak dan biaya penagihan pajak. Dilakukan dengan cara menegur atau memperingatkan. Melakukan penagihan seketika dan sekaligus memberitahukan surat paksa. Mengusulkan pencegahan, melakukan penyitaan, melakukan penyanderaan, menjual barang yang telah disita (Rahayu, 2010).

Penagihan pajak dikelompokkan kedalam 2 (dua) kategori (Suandy, 2008), yaitu penagihan pasif dan penagihan aktif:

1) Penagihan Pajak Pasif

Penagihan pajak yang dilaksanakan menggunakan Surat Tagihan Pajak (STP), Surat Ketetapan Pajak Kurang Bayar (SKPKB), Surat Ketetapan Pajak Kurang Bayar Tambahan (SKPKBT). Surat keputusan pembetulan yang mengakibatkan pajak terutang menjadi lebih besar, surat keputusan keberatan yang mengakibatkan pajak terutang menjadi lebih besar. Jika dalam jangka waktu 30 (tiga puluh) hari belum dilunasi, maka tujuh hari setelah jatuh tempo akan dilakukan penagihan pajak aktif yang dilaksanakan dengan menerbitkan surat teguran.

2) Penagihan Pajak Aktif 
Adalah tindakan lanjutan penagihan pajak pasif. Dalam tindakan penagihan ini maka fiskus berperan aktif dengan tidak hanya mengirim surat tagihan atau surat ketetapan pajak tetap, tetapi juga akan bisa diikuti dengan tindakan sita, dan diselesaikan dengan tindakan pelaksanaan lelang. berikut :

Penagihan Pajak melalui Surat Paksa dilaksanakan dengan tahapan-tahapan sebagai

1) Penagihan pajak dilaksanakan dengan menerbitkan surat teguran terlebih dahulu.

2) Wajib pajak dapat mengajukan keberatan atas SKPKB, SKPKBT. Jangka waktu untuk pelunasan pajak pada jumlah pajak yang belum dibayar pada saat pengajuan keberatan yaitu sebesar pajak yang tidak disetujui dalam pembahasan akhir hasil pemeriksaan tertangguh selama 1 (satu) bulan sejak tanggal penerbitan surat keputusan keberatan.

3) Wajib pajak dapat mengajukan banding atas surat keputusan keberatan yang terkait dengan SKPKB atau SKPKBT. Jangka waktu pelunasan pajak akan tertangguh 1 (satu) satu bulan sejak tanggal penerbitan putusan banding.

4) Tidak diterbitkan surat teguran terhadap persetujuan untuk mengangsur atau menunda pembayaran pajak.

5) Diterbitkan surat teguran.

6) Penyampaian surat teguran dapat dilaksanakan dengan cara:

a. langsung.

b. pos.

c. jasa kurir dengan bukti penagihan surat.

7) Jika wajib pajak tidak melunasi jumlah utang setelah lewat 21 hari sejak tanggal penyampaian surat teguran, maka surat paksa diterbitkan. Hal ini diberitahukan secara langsung oleh juru sita pajak kepada wajib pajak.

8) Surat paksa dapat diterbitkan ketika: atau

a. Telah dilaksanakan penagihan secara seketika dan sekaligus terhadap wajib pajak,

b. Wajib pajak tidak memenuhi ketentuan yang tercantum dalam keputusan persetujuan angsuran atau penundaan pembayaran pajak.

9) Juru sita pajak melakukan penagihan seketika dan sekaligus mengindahkan tanggal jatuh tempo pembayaran dalam kondisi: untuk itu.

a. Wajib pajak akan meninggalkan Indonesia untuk selama-lamanya atau ada niat

b. Wajib pajak memindah tangankan barang yang dimiliki atau yang dikuasai dalam upaya menghentikan atau mengecilkan kegiatan perusahaan atau pekerjaan yang dilaksanakannya di Indonesia.

c. Muncul tanda-tanda bahwa wajib pajak akan membubarkan badan usaha, memekarkan usaha, dan memindahtangankan perusahaan yang dimiliki atau yang dikuasainya, atau melakukan perubahan bentuk lainnya.

d. Badan usaha akan dibubarkan negara atau terjadi tindakan penyitaan atas barang wajib pajak oleh pihak ketiga atau muncul tanda-tanda kepailitan.

10) Surat paksa disampaikan juru sita pajak kepada wajib pajak dengan pernyataan dan penyerahan salinan surat. 
11) Surat paksa akan disampaikan kepada orang pribadi atau badan.

12) Jika wajib pajak atau pihak-pihak yang dimaksud menolak untuk menerima surat paksa, juru sita pajak meninggalkan surat paksa tersebut dan mencatatnya dalam berita acara bahwa wajib pajak pajak tidak mau menerima surat paksa dan surat paksa dianggap telah diberitahukan.

13) Manakala pemberitahuan surat paksa tidak dapat dilakukan, surat paksa disampaikan melalui pemerintah daerah setempat.

14) Manakala tempat tinggal, tempat usaha, atau tempat kedudukan wajib pajak atau wajib pajak tidak diketahui, penyampaian surat paksa dilaksnakan dengan menempelkan salinan surat paksa pada papan pengumuman kantor pejabat yang menerbitkannya, pengumuman melalui media massa, ataupun dengan cara lain.

15) Manakala pelaksanaan surat paksa dilaksanakan di luar wilayah kerja pejabat. Atas diterbitkannya surat paksa tersebut diminta bantuan kepada pejabat yang wilayah kerjanya meliputi tempat pelaksanaan surat paksa.

16) Setelah lewat $2 \times 24$ jam sejak surat paksa disampaikan kepada wajib pajak sebagaimana dimaksud dalam Pasal 12 dan utang pajak tidak dilunasi oleh wajib pajak, pejabat menerbitkan surat perintah melakukan penyitaan.

17) Berdasarkan surat perintah melakukan penyitaan, juru sita pajak melakukan penyitaan terhadap barang milik wajib pajak.

18) Manakala wajib pajak tidak melunasi utang pajak dan biaya penagihan pajak setelah lewat tengat waktu 14 hari sejak tanggal jatuh tempo penyitaan, pejabat melakukan pengumuman lelang.

19) Pengumuman lelang dilaksanakan 1 kali, sedangkan untuk barang tidak bergerak dilaksanakan 2 kali.

20) Jika wajib pajak tidak melunasi utang pajak dan biaya penagihan pajak setelah lewat waktu 14 hari sejak pengumuman lelang, pejabat melakukan penjualan barang sitaan wajib pajak melalui kantor lelang negara.

\section{Nomor Pokok Wajib Pajak (NPWP)}

Nomor pokok wajib pajak (NPWP) merupakan nomor identitas yang diterbitkan kepada wajib pajak untuk sarana dalam administrasi perpajakan yang dipergunakan sebagai tanda pengenal atau identitas wajib pajak dalam melaksanakan hak dan dan atuapun kewajiban perpajakannya (Mardiasmo, 2011).

Masyarakat yang sudah memenuhi persyaratan subjektif dan objektif menurut ketentuan peraturan perundang-undangan perpajakan dengan metode sistem self assessment, wajib mendaftarkan diri melalui kantor DJP untuk dicatatkan sebagai wajib pajak dan diterbitkan nomor pokok wajib pajak (NPWP). Persyaratan objektif adalah persyaratan atas subjek pajak yang mendapatkan penghasilan atau yang diwajibkan untuk pemotongan/ pemungutan menurut ketentuan UU Pajak Penghasilan 1984 dan perubahannya (Anastasya, 2009).

Sehubungan dengan tata cara pendaftaran NPWP, orang pribadi atau badan usaha mengisi Formulir Permohonan Pendaftaran Wajib Pajak dan/atau Formulir Permohonan Pengukuhan PKP. Diisi secara lengkap dan jelas serta ditandatangani oleh wajib pajak atau kuasanya kemudian diserahkan kepada petugas pendaftaran wajib pajak. Manakala permohonan ditandatangani oleh orang lain, wajib menyertakan memiliki surat kuasa khusus.

Dalam pengisian Formulir Pendaftaran, wajib pajak wajib menyertakan data pendukung yang diperlukan, sebagai berikut (Tansuria, 2010): 
1) Bagi WPOP yang menjalankan atau tidak menjalankan usaha atau pekerjaan bebas dengan melampirkan KTP bagi penduduk Indonesia, atau paspor bagi orang asing.

2) Bagi WP Badan

a. Akte pendirian beserta perubahannya atau surat keterangan penunjukkan dari kantor pusat bagi BUT.

b. NPWP penanggung jawab WP Badan. jawab.

c. KTP bagi penduduk Indonesia atau paspor bagi orang asing untuk penanggung

3) Bagi Bendahara wajib memungut atau memotong:

a. Surat penetapan sebagai Bendahara.

b. KTP.

4) Bagi Joint Operation sebagai WP wajib memungut atau memotong:

a. Surat Perjanjian Kerjasama atau Akta Pendirian Joint Operation. jawab.

b. KTP bagi penduduk Indonesia atau paspor bagi orang asing untuk penanggung

5) NPWP Pimpinan atau Penanggung Jawab Joint Operation.

6) Bagi pemohon dengan status cabang, WPOP pengusaha tertentu atau wanita kawin tetapi tidak pisah harta, diwajibkan NPWP Kantor Pusat atau domisili suami.

Menurut Mardiasmo (2011), manfaat NPWP, sebagai berikut:

1) Sebagai sarana administrasi perpajakan.

2) Tanda pengenal atau Identitas Wajib Pajak bagi pelaksanaan hak dan kewajiban perpajakannya.

3) Untuk pencantuman bagi setiap dokumen perpajakan.

4) Melaksanakan ketertiban dalam pembayaran pajak, pengawasan , dan administrasi perpajakan.

Untuk penghapusan NPWP wajib pajak dilaksanakan oleh DJP Pajak dengan syarat (Tansuria, 2010):

WP tidak memenuhi persyaratan subjektif dan/atau objektif, contohnya WPOP yang meninggal dunia dan tidak meninggalkan warisan.

WP Badan melaksanakan likuidasi atau pembubaran disebabkan penghentian atau penggabungan usaha.

Wanita yang memiliki NPWP dan menikah tapi tidak membuat perjanjian pemisahan harta dan atau penghasilan.

WP BUT yang menghentikan usahanya di Indonesia.

Warisan belum terbagi yang dalam kedudukan sebagai Subjek Pajak sudah terbagi.

DJP menganggap perlu untuk menghapus NPWP wajib pajak yang tidak memenuhi persyaratan subjektif dan/atau objektif sesuai ketentuan peraturan perundang-undangan perpajakan.

Adapun sanksi bagi yang diwajibkan memiliki NPWP namun tidak mendaftarkan diri untuk memporolehnya, maka menurut Pasal 39 ayat 1 UU nomor 28 tahun 2007, yaitu:

1) Setiap orang dengan sengaja : 
a. Tidak melakukan pendaftaran diri untuk diberikan NPWP atau tidak melaporkan usaha untuk dikukuhkan sebagai PKP

b. Menyalahgunakan atau menggunakan tanpa hak atas NPWP atau pengukuhan PKP

c. Tidak melakukan penyampaian Surat Pemberitahuan

d. Memberikan Surat Pemberitahuan dan atau keterangan diamana isinya tidak benar dan atau tidak lengkap

e. Menolak untuk dilaksanakan pemeriksaan sebagaimana tercantum dalam Pasal 29

f. Memberikan pembukuan, pencatatan, atau dokumen lain yang palsu atau dipalsukan seolah-olah benar, atau tidak menggambarkan keadaan yang sebenarnya

g. Tidak melakukan pembukuan atau pencatatan, tidak memperhatikan atau tidak meminjamkan catatan atau dokumen lain

h. Tidak melakukan penyimpanan catatan atau dokumen yang menjadi dasar bagi pembukuan atau pencatatan maupun dokumen lainnya. Termasuk hasil pengolahan data dari pembukuan yang dikelola secara elektronik atau program aplikasi on-line sebagaimana tercantum dalam Pasal 28 ayat 11

i. Tidak menyetorkan pajak yang telah dipotong atau dipungut yang berpotensi menimbulkan kerugian negara dapat dipidana dengan pidana penjara paling singkat 6 bulan dan paling lama 6tahun dan denda paling sedikit 2 kali jumlah pajak terutang yang tidak atau kurang dibayar dan paling banyak 4 kali jumlah pajak terutang yang kurang dibayar.

2) Pidana tercantum pada ayat 1 dapat ditambahkan 1 kali menjadi 2 kali sanksi pidana apabila melakukan lagi tindak pidana perpajakan sebelum lewat 1 (satu) tahun, yang dihitung sejak selesainya menjalani pidana penjara.

3) Setiap orang yang melakukan percobaan tindak pidana menyalahgunakan atau menggunakan tanpa hak NPWP atau pengukuhan PKP sebagaimana dimaksud pada ayat 1 huruf $b$, atau menyampaikan Surat Pemberitahuan dan atau keterangan yang isinya tidak benar atau tidak lengkap, sebagaimana tercantum pada ayat 1 huruf $d$, dalam rangka mengajukan restitusi atau kompensasi pajak atau pengkreditan pajak. Hal tersebut dapat dipidana penjara paling singkat 6 bulan dan paling lama 2 tahun dan denda paling sedikit 2 kali jumlah restitusi dan atau kompensasi yang dimohonkan atau pengkreditan yang dilaksanakan dan paling banyak 4 kali jumlah restitusi dan atau kompensasi yang dimohonkan yang dilaksanakan.

UU Nomor 36 Tahun 2008 tentang pajak penghasilan Pasal 21 ayat 5a, Pasal 22 ayat 3 dan Pasal 23 ayat 1a menyebutkan:

\section{1) Pasal 21 ayat (5a)}

Pasal ini menyebutkan bahwa pemotongan PPh Pasal 21 harus menerapkan tarif yang lebih tinggi $20 \%$ terhadap Wajib Pajak yang tidak memiliki Nomor Pokok Wajib Pajak (NPWP) dibanding tarif yang ditetapkan terhadap Wajib Pajak yang dapat menunjukkan Nomor Pokok Wajib Pajak. dan sedikit tambahan Khusus untuk Pasal 21 (imbalan sehubungan dengan pekerjaan), pihak pemberi kerja (swasta, besndaharawan) dan pekerja (karyawan, PNS) akan sama- sama dirugikan kalau ada karyawan yang tidak memiliki NPWP. Oleh karena mekanisme pembayaran pajak Pasal 21 bagi swasta biasanya ditanggung oleh pemberi kerja, sedangkanbagi PNS, khusus denda Pasal 21 akibat tidak punya NPWP, pajaknya akan ditanggung oleh PNS itu sendiri.

2) Pasal 22 ayat (3)

Dalam pasal ini disebutkan bahwa pemungut $\mathrm{PPh}$ pasal 22 harus menerapkan tarif yang lebih tinggi $100 \%$ terhadap Wajib Pajak yang tidak memiliki NPWP dibanding tarif yang diterapkan terhadap Wajib Pajak yang dapat menunjukkan NPWP 


\section{3) Pasal 23 ayat (1a)}

Pasal ini menyebutkan bahwa pemotong PPh Pasal 23 harus menerapkan tarif yang lebih tinggi $100 \%$ terhadap Wajib Pajak yang tidak memiliki NPWP dibanding tarif yang diterapkan terhadap Wajib Pajak yang dapat menunjukkan NPWP.

\section{Kesadaran Wajib Pajak}

kesadaran merupakan keinsafan; keadaan mengerti dan kesadaran seseorang akan nilai -nilai di dalam diri manusia mengenai hukum yang ada; kesadaran akan pengetahuan mengenai suatu perilaku tertentu diatur oleh hukum. Dapat diartikan kesadaran wajib pajak merupakan suatu kondisi yang mana wajib pajak mengetahui, mengerti serta melakukan ketentuan perpajakan dengan cara yang benar dan sukarela (KBBI, 2017).

Ketepatan dalan menyampaikan pelaporan SPT bagi WP dipengaruhi olrh beberapa faktor yang salah satunya adalah kesadaran wajib pajak. Kesadaran wajib pajak merupakan kondisi WP mengetahui, mengerti dan melakukan ketentuan perpajakan secara benar dan sukarela. Semakin tinggi kesadaran WP maka pemahaman dan pelaksanaan kewajiban perpajakan semakin baik bagi peningkatan penerimaan pajak (Muliari, 2011).

WP harus mengikuti aturan secara benar dan sukarela. Kesadaran WP merupakan kondisi dimana WP mengetahui, mengakui, menghargai dan mentaati ketentuan perpajakan yang berlaku dan memiliki keinginan serta bersungguh-sungguh untuk melaksanakan kewajibannya.

WP dapat dimakanai memiliki kesadaran dengan ketentuan (Manik, 2009) :

Memahami tentang adanya UU dan ketentuan perpajakan

Memahami fungsi pajak bagi penerimaan negara

Mengerti kewajiban perpajakan harus dilakukan sesuai dengan peraturan yang berlaku

Menghitung, melaporkan, dan membayar pajak secara sukarela

Menghitung, melaporkan, dan membayar, pajak secara benar

Anggraeni (2013) menyebutkan kriteria WP yang sadar akan kewajiban terkait perpajakannya secara self-assessment, yaitu:

1. Untuk memperoleh NPWP, WP wajib aktif mendaftarkan diri dan mandiri ke KPP setempat.

2. WP mendapatkan sendiri formulir SPT Masa di KPP setempat.

3. WP tanpa bantuan fiskus, menghitung dan menetapkan sendiri jumlah pajak penghasilan yang terutang melalui pengisian SPT.

4. WP tanpa harus ditagih fiskus, menyetor dan melaporkan formulir SPT secara aktif, mandiri dan tepat waktu.

\section{Penerimaan Pajak}

Pajak adalah iuran masyarakyat kepada kas Negara berdasarkan UU yang dapat dipaksakan tanpa mendapat jasa timbal atau kontra prestasi yang langsung dapat ditunjukkan, yang digunakan untuk membayar pengeluaran umum (Mardiasmo, 2011). Unsur-unsur dari pengertian tersebut, sebagai berikut :

1) Pajak dipungut berdasarkan UU.

2) Tanpa timbal jasa atau kontra prestasi secara langsung.

3) Dapat dipaksakan.

4) Penerimaannya bagi pembiayaan pembangunan. 
Menurut Mardiasmo (2011), bahwa pajak adalah sumber penerimaan Negara yang mempunyai 2 fungsi yaitu :

1) Sebagai fungsi anggaran (budgetair) yaitu sumber dana bagi pemerintah, untuk membiayai pengeluaran pemerintah.

2) Sebagai fungsi mengatur (regulerend) yaitu alat pengatur bagi pemerintah dalam bidang sosial ekonomi.

Sedangkan pemungutan pajak dapat dibagi menjadi tiga ssistem yaitu:

1) Official Assessment System

Sistem pemungutan yang memberi wewenang pemerintah (fiskus) untuk menentukan besarnya pajak yang terutang oleh WP.

2) Self Assessment System

Sistem pemungutan yang memberi wewenang sepenuhnya WP untuk menghitung, memperhitungkan, membayar, dan melaporkan sendiri besarnya pajak yang terutang.

3) Witholding System

Sistem pemungutan yang memberi wewenang kepada pihak ketiga untuk menentukan besarnya pajak yang terutang oleh WP.

\section{Hubungan Penagihan Wajib Pajak dan Kesadaran Wajib Pajak}

Salah satu bentuk penagihan terhadap WP yaitu penerbitan produk hukum berupa STP oleh DJP di wilayah kerja KPP tertentu, di mana menurut pasal 14 ayat 1 UU No. 28 Tahun 2007 j.o. PMK No. 145/PMK.03/2012, dimana STP ini dapat diterbitkan dengan kondisi:

a. Pajak Penghasilan tahun berjalan tidak atau kurang dibayar;

b. berdasarkan penelitian terdapat kekurangan pembayaran pajak sebagai akibat salah tulis atau salah hitung;

c. WP dikenai sanksi administrasi denda dan atau bunga;

d. pengusaha sebagai PKP, tetapi tidak membuat faktur pajak atau membuat faktur pajak tetapi tidak tepat waktu;

e. pengusaha sebagai PKP tidak mengisi faktur pajak secara lengkap sebagaimana tercantum dalam Pasal 13 ayat 5 UU PPN 1984 dan perubahannya.

\section{f. PKP melaporkan faktur pajak tidak sesuai masa penerbitan faktur pajak;}

g. PKP gagal berproduksi dan telah diberikan pengembalian Pajak Masukan sebagaimana tercantum Pasal 9 ayat 6a UU PPN 1984 dan perubahannya.

Pemerintah memberlakukan hukum secara adil bagi WP maupun fiskus menjadi sarana efektif untuk meningkatkan kesadaran membayar pajak. Pemerintah juga memastikan hasil pembayaran pajak digunakan untuk menyediakan fasilitas-fasilitas umum, pelayanan baik di bidang pendidikan, kesehatan, dan infrastruktur. Pemerintah juga terus mengembangkan sistem pemungutan pajak yang lebih baik, sederhana, dan efisien untuk mengurangi kemungkinan adanya pelanggaran terhadap peraturan hukum pajak (Kompasiana, 2010).

\section{Hubungan Kewajiban Kepemilikan NPWP dan Kesadaran Wajib Pajak}

Berdasarkan peraturan perundang-undangan perpajakan dengan sistem self assessment, WP pajak yang memenuhi persyaratan subjektif dan objektif, wajib mendaftarkan diri melalui kantor DJP untuk mencatatkan diri sebagai WP dan mendapatkan NPWP. Persyaratan objektif adalah persyaratan subjek pajak yang memperoleh penghasilan atau diwajibkan untuk melakukan pemotongan atau pemungutan sesuai UU Nomor 28 tahun 
2007 tentang ketentuan umum dan tata cara perpajakan pasal 2 ayat 1. Pengesahan NPWP dengan pemberian Surat Keterangan Terdaftar yang tersebut menginformasikan pemenuhan kewajiban perpajakan kepada WP.

Kewajiban perpajakan WP tersebut diisi dan dilaksanakan oleh setiap WP. Pemenuhan kewajiban perpajakan harus berdasarkan ketentuan peraturan perundang-undangan perpajakan yang berlaku untuk dapat dapat mengamankan penerimaan pajak bagi negara. Dengan pemenuhan kewajiban perpajakan oleh WP secara benar dan tepat akan meningkatkan penerimaan dari pajak.

\section{Hubungan Kesadaran Wajib Pajak dan Penerimaan Pajak}

Salah satu penerimaan negara dari sektor pajak berasal dari Pajak Penghasilan (PPh). $\mathrm{PPh}$ di Indonesia dipungut dengan sistem self-assessment yang mensyaratkan WP Pajak untuk menghitung, menyetor, dan melaporkan sendiri pajak. Penerapan sistem selfassessment bertujuan supaya administrasi perpajakan lebih mudah, murah, dan efisien. Melalui sistem ini, pemerintah tidak lagi berperan terlalu aktif. Self-assessment membutuhkan kesadaran WP untuk patuh melaksanakan kewajiban perpajakannya. Semakin tinggi kesadaran WP untuk tepat waktu menyetor pajak, diharapkan semakin besar pula penerimaan pajak negara (Pormando, 2009)

Menurut Atarwaman, 2020, bahwa pengaruh Kesadaran WP adalah suatu kondisi dimana wajib pajak mengetahui, memahami kemudian melaksanakan ketentuan perpajakan secara benar dan sukarela. Kesadaran WP akan perpajakan merupakan rasa yang timbul dari dalam diri WP berupa kewajibannya membayar pajak dengan ikhlas tanpa unsur paksaan. Melalui kesadaran pajak yang tinggi makakepatuhan WP terhadap kewajiban pajaknya dapat meningkat.

Berdasarkan suatu penelitian didapatkan kesimpulan bahwa kesadaran Wajib Pajak mempunyai pengaruh signifikan, baik secara parsial maupun simultan terhadap penerimaan pajak penghasilan di KPP Mataram. Kesadaran WP dalam penelitian tersebut diukur dengan metode kuesioner yang dibagikan langsung kepada WP OP aktif, dengan menggunakan data penerimaan PPh pasal 25 di KPP Mataram dari tahun 2005-2007 (Sutanto, 2009)

\section{Teori Utama Dalam Penelitian}

Suatu penelitian adalah usaha mencari kebenaran bersifat ilmiah. Untuk itu diperlukan teori pada posisi yang tepat. Penggunaan teori sangat bergantung pada jenis penelitian yang dilaksanakan. Dalam penelitian kuantitatif, teori dipakai sebagai landasan awal dalam merumuskan masalah, menentukan kerangka berpikir dan merumuskan hipotesis. Dalam penelitian kualitatif teori menduduki posisi akhir sebagai hasil dari proses penelitian. Peranan teori dalam suatu penelitian sangat bergantung pada jenis penelitian dan pada obyek yang dikaji oleh peneliti.

\section{Theory of Planned Behavior}

Menurut Hidayat (2010), bahwa pendekatan aspek psikologi dilaksanakan mengingat dalam suatu negara demokrasi, hubungan pembayar pajak dengan otoritas pajak dilihat sebagai suatu kontrak psikologi. Hal tersebut menuntut adanya hubungan yang setara antara pembayar pajak tergantung dan dari seberapa besar kedua belah pihak saling mempercayai, mematuhi dan memenuhi komitmen dalam kontrak tersebut

Teori dalam bidang psikologi perihal faktor yang mempengaruhi perilaku kepatuhan pajak diantaranya adalah Theory of Planned Behavior (TPB) oleh Ajzen (Hidayat, 2010). Menurut Ajzen (1991), bahwa perilaku individu untuk patuh terhadap ketentuan perpajakan ditentukan niat, yang dipengaruhi oleh 3 faktor, yaitu:

\section{Behavioral Beliefs}

Berasal dari keyakinan individu akan akibat dari suatu perilaku dan analisa terhadap 
akibat akan keyakinan tersebut. Analisa dan keyakinan terhadap akibat tersebut membentuk variabel sikap

\section{2) Normative Beliefs}

Berasal dari keyakinan individu akan harapan normatif orang sebagai rujukan seperti keluarga, rekan dan konsultan pajak beserta motivasi untuk mencapai harapan tersebut. Harapan normatif yang muncul akan membentuk variabel norma subjektif

\section{3) Control Beliefs}

Berasal dari keyakinan individu akan keberadaan variabel yang mendukung atau menghambat perilaku dan keyakinannya seberapa kuat variabel tersebut mempengaruhi perilakunya. control beliefs akan membentuk variabel kontrol perilaku yang diyakini.

Menurut Mustikasari (2007), bahwa behavioral beliefs, normative beliefs, dan control beliefs merupakan tiga faktor yang mengarahkan perilaku individu. Setelahnya individu akan memasuki tahap intention, dan terakhir adalah behavior. Tahap intention adalah tahapan suatu individu memiliki niat untuk berperilaku, sedangkan behaviour adalah tahap individu berperilaku.

\section{Teori Atribusi}

Dikemukakan Harold Kelley pada tahun 1972, merupakan pengembangan teori atribusi yang dicetuskan Fritz Heider di tahun 1958. Teori ini menyampaikan suatu individu ketika perilaku individu lainnya. individu tersebut menganalisa untuk menentukan apakah penyebab perilaku tersebut adalah secara internal atau eksternal (Robbins, 2008).

Perilaku karena penyebab secara internal merupakan perilaku individu yang diyakini berada di bawah kendali pribadi seorang individu. Perilaku karena penyebab secara eksternal diyakini sebagai akibat dari sebab-sebab luar, dimana individu tersebut berperilaku demikian karena dipaksa oleh situasi diluar individu. Penentuan apakah penyebab pengaruh perilaku secara internal atau eksternal adalah 3 faktor, yaitu (Robbins dan Judge, 2008) :

\section{Kekhususan}

Hal tersebut merujuk pada perilaku individu yang memperlihatkan perilaku-perilaku yang berbeda pada situasi-situasi yang berbeda. Ketika perilaku tersebut dianggap biasa maka penyebab perilaku tersebut adalah secara internal. Ketika perilaku tersebut dianggap tidak biasa maka penyebab perilaku tersebut adalah secara eksternal.

\section{Konsensus}

Hal tersebut merujuk pada apakah setiap iindividu ketika menghadapi situasi yang serupa akan bereaksi dengan cara yang sama. Ketika dicapai konsensus rendah maka penyebab perilaku tersebut adalah secara internal. Ketika dicapai konsensus tinggi maka penyebab perilaku adalah secara eksternal.

\section{Konsistensi}

Hal tersebut merujuk pada apakah setiap individu akan bereaksi dengan cara yang sama. Ketika semakin konsisten perilaku maka penyebab perilaku tersebut adalah secara internal. Ketika semakin tidak konsisten perilaku maka penyebab perilaku tersebut adalah secara eksternal.

Menurut Jatmiko (2006), bahwa teori atribusi dapat menjelaskan faktor-faktor yang mempengaruhi variabel kesadaran WP pajak dalam model penelitian ini. Kesadaran WP terkait dengan sikap WP dalam membuat penilaian terkait pajak itu sendiri. Karenanya persepsi individu untuk menilai individu lain sangat dipengaruhi oleh faktor secara internal atau eksternal individu lainnya.

\section{Kerangka Pemikiran}




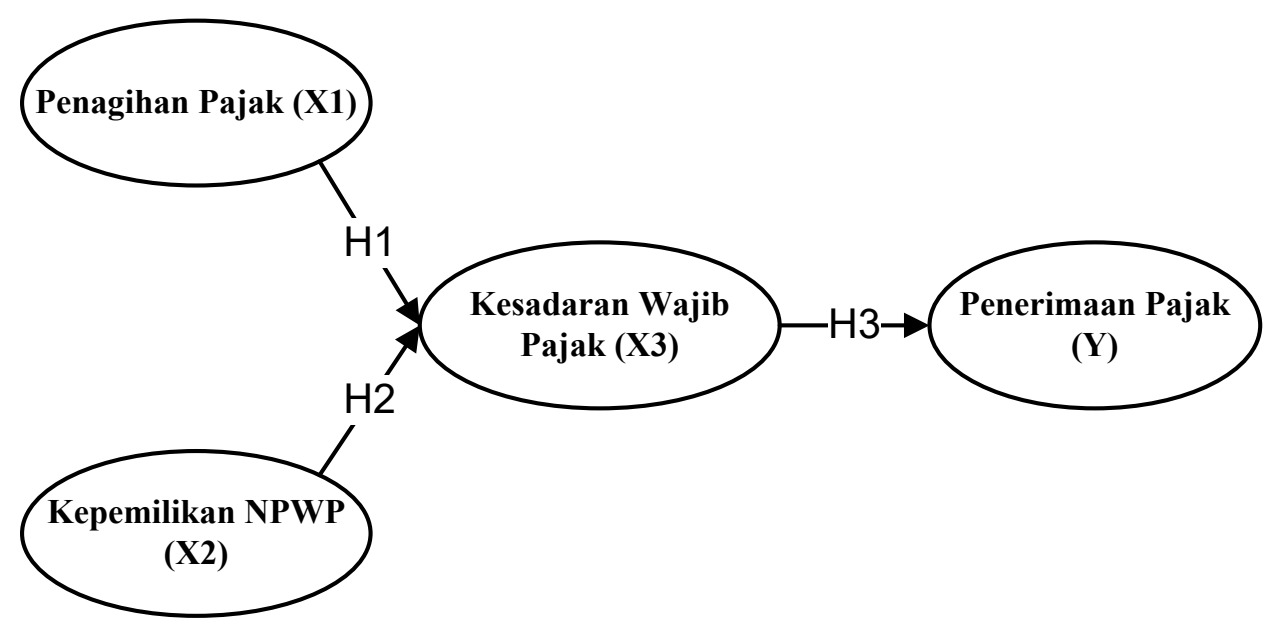

\section{Hipotesis}

Dari kerangka hubungan antar konstruk dalam kerangka pemikiran dapat dihipotesiskan sebagai berikut

1) Penagihan Pajak (X1) berpengaruh positif dan signifikan terhadap Kesadaran Wajib Pajak (X3).

2) Kepemilikan NPWP (X2) berpengaruh positif dan signifikan terhadap Kesadaran Wajib Pajak (X3).

3) Kesadaran Wajib Pajak (X3) berpengaruh positif dan signifikan terhadap Penerimaan Pajak (Y).

4) Penagihan Pajak (X1) berpengaruh terhadap Penerimaan Pajak (Y) Melalui Kesadaran Wajib Pajak (X3).

5) Kepemilikan NPWP (X2) berpengaruh terhadap Penerimaan Pajak (Y) Melalui Kesadaran Wajib Pajak (X3).

\section{Metode}

\section{Lokasi Penelitian}

Penelitian ini dilaksanakan pada Kantor Pelayanan Pajak (KPP) Pratama di Kabupaten Gianyar, sedangkan objek dalam penelitian ini adalah WP Badan yang berada di KPP Pratama Kabupaten Gianyar. Penelitian ini dilaksanakan untuk memperoleh data terkait dengan masalah yang diteliti, dimana Variabel Independen dalam penelitian ini yaitu penagihan pajak, kewajiban kepemilikan NPWP, dan kesadaran wajib pajak mempengaruhi variable dependen yaitu penerimaan pajak. Alamat dari KPP Pratama wilayah Gianyar adalah di Jl. By Pass Dharma Giri, Ds. Buruan, Kec. Blahbatuh, Kabupaten Gianyar

\section{Desain Penelitian}

Penelitian ini dilaksanakan dengan menggunakan desain penelitian campuran (mixed method), yaitu penelitian yang menggabungkan antara desain penelitian kuantitatif dan kualitatif (Sugiyono, 2011). Data diperoleh dengan melaksanakan survei lapangan pada WP badan yang terdaftar di di KPP Pratama wilayah Gianyar sebagai anggota sampel. Penelitian dirancang dengan metode survey sample. Hal ini dimaksudkan untuk menggali informasiinformasi dari sebagian populasi untuk mewakili seluruh populasi. Penelitian survei merupakan penelitian yang dilaksanakan pada populasi besar atau kecil, tetapi data yang dianalisa adalah data dari sampel. Berdasarkan analisa, akan ditemukan kejadian-kejadian 
relatif, distribusi dan hubungan-hubungan antar variabelnya baik secara sosiologi maupun psikologis (Sugiyono, 2011). Pengumpulan data secara cross section dengan memakai daftar pertanyaan yang kemudian dianalisis secara metode kuantitatif dan kualitatif.

Analisis kuantitatif menggunakan alat statistik, baik statistik deskripstif maupun statistik inferensial. Statistik deskriptif dimaksudkan untuk memberi gambaran karakteristik dari responden dan deskripsi pada variabel penelitian. Statistik inferensial dengan menggunakan Structural Equation Modeling (SEM) dimaksudkan untuk malukan uji hipotesis penelitian. Selanjutnya hasil analisis kuantitatif dibahas secara kualitatif dengan menguraikan setiap variabel penelitian dan membahas hubungan antar variabel untuk kemudian dibandingkan dengan hasil-hasil penelitian sebelumnya.

Penggunaan metode kuantitatif karena metode kuantitatif kuat dengan prinsip normalitas distribusinya pada penggunaan metode statistik, sehingga dapat diandalkan dalam generalisasi. Namun metode kuantitatif lemah dalam hal kedalaman analisis. Metode kuantitatif tidak mampu mengungkap permasalahan secara mendalam terutama fenomenas spesifik yang tidak sejalan dengan teori. Sedangkan metode kualitatif memiliki keunggulan terutama pada kedalaman analisis. Metode kualitatif mampu menggali berbagai informasi secara dalam terhadap informan. Akan tetapi metode kualitatif memiliki kelemahan perihal generalisasi. Penggunaan metode campuran dalam penelitian ini bertujuan untuk menutupi kelemahan dari kedua metode tersebut (Sugiyono, 2011).

\section{Jenis dan Sumber Data}

Menurut Mantra (2001), bahwa menurut sifatnya, data dapat dibedakan menjadi 2, yaitu data kualitatif dan data kuantitatif.

a) Data kualitatif merupakan data yang tidak berbentuk angka tetapi berupa penjelasan atau keterangan yang memberikan gambaran terhadap pembahasan permasalahan dalam penelitian ini.

b) Data kuantitatif merupakan data yang berbentuk angka-angka yang digunakan dalam penelitian ini untuk diolah untuk menjawab permasalahan dalam penelitian ini.

Sedangkan menurut sumbernya, data terdiri dari:

a) data primer merupakan hasil wawancara terstruktur terhadap responden dengan menggunakan daftar pertanyaan yang telah dipersiapkan sebelumnya;

b) data sekunder merupakan data yang dikumpulkan oleh instansi, terutama instansi terkait dengan penelitian ini. Jenis data tersebut antara lain: gambaran umum daerah penelitian, gender, umur; status pekerjaan, status perkawinan, status keluarga.

\section{Teknik Pengumpulan Data}

Untuk memperoleh data yang diperlukan diperlukan dalam penelitian ini, dengan menggunakan beberapa teknik pengumpulan data. sebagai berikut:

\section{a. Kuisioner}

Data diperoleh dengan menyiapkan daftar pertanyaan (kuesioner), kemudian melakukan wawancara terstruktur. Dilaksanakan uji coba (try out) terlebih dahulu pada daftar pertanyaan yang digunakan untuk pengumpulan data. Hal ini bertujuan untuk melihat efektivitas dari berbagai pertanyaan yang disusun dalam daftar pertanyaan dan jawaban responden. Bentuk dari pertanyaan ada yang berbentuk tertutup. Pada pertanyaan tertutup, responden akan memilih salah satu jawaban beberapa jawaban yang diberikan pertanyaan tanpa memberikan alternatif jawaban lainnya. Pada pertanyaan terbuka, responden diberikan untuk menjawab bebas dari pertanyaan-pertanyaan dalam daftar pertanyaan dengan mengisi kolom yang telah disediakan terkait dengan pilihan pilihan pada pertanyaan tertutup. Pertanyaan ini dilaksanakan untuk kedalaman mengindentifikasi permasalahan dalam penelitian ini. 


\section{b. Dokumentasi}

Data diperoleh melalui cara membaca, mempelajari maupun mengutip pendapat dari bermacam sumber seperti buku, jurnal, laporan, atau dokumen dan sumber lainnya yang terkait dengan permasalahan yang diteliti.

\section{Populasi dan Sampel}

Sampel dari penelitian ini dipilih dengan teknik Nonprobability Sampling Design. Dengan teknik tersebut, pengambilan sampel akan tidak memberi peluang atau kesempatan sama bagi setiap unsur-unsur anggota populasi untuk dipilih menjadi sampel (Sugiyono, 2009). Metode terpilih dipilih adalah convinience sampling. convinience sampling. Dalam teknik ini, unit sampel yang ditarik mudah dihubungi, tidak menyusahkan, mudah untuk mengukur dan bersifat kooperatif (Hamid,2010). Metode yang digunakan untuk menentukan jumlah sampel berdasarkan perhitungan penentuan sampel dengan rumus slovin.

Setelah melakukan perhitungan, maka jumlah sampel sebanyak 100 orang dari populasi dalam penelitian ini yaitu wajib pajak yang terdaftar di di KPP Pratama wilayah Gianyar. Jumlah responden mengacu pada pendekatan Partial Least Square (PLS) pada penelitian ini berorientasi pada prediksi (predictive research). PLS berasumsi data penelitian bebas distribusi (distribution free), bermakna data penelitian tidak merujuk pada salah satu distribusi tertentu. PLS adalah metode alternatif dari Structural Equation Modeling (SEM) yang mampu untuk digunakan dalam hal mengatasi permasalahan suatu hubungan diantara variabel yang kompleks akan tetapi ukuran sampel datanya kecil. Analisis SEM PLS juga dipergunakan bila ditemukan adanya dimensi formatif terkait dengan variabel penelitian (Hair, et.al., 2012).

\section{Instrumen Penelitian dan Pengujian}

Suatu instrumen dalam suatu penelitian harus valid dan reliabel (Ferdinand, 2014), bahwa. Suatu instrumen dapat dikatakan valid dan reliabel melalui melalui uji validitas dan realibilitas. Adapun kriteria suatu instrumen dikatakan valid maupun reliabel adalah sebagai berikut.

\section{a. Validitas}

Uji validitas akan memberi petunjuk kemampuan alat ukur untuk mengukur apa yang ingin diukur (Danim, 1997). Validitas data ditentukan pada keadaan responden saat diwawancarai (Umar, 2002). Uji validitas untuk memastikan bahwa pengukuran telah memasukkan kumpulan item yang memadai dan mewakili untuk mengungkapkan sebuah konsep (Sekaran, 2006).

Untuk mengetehui kevalidan indikator-indikator sebagai pengukur variabel laten maka dilaksanakan uji pearson product momen.

\section{b. Reliabilitas}

Uji reliabilitas mengacu sejauh mana suatu hasil pengukuran memberikan hasil relatif konsisten apabila suatu pengukuran diulang berkali-kali (Umar, 2002). Apabila alat ukur (kuesioner) dipakai 2 kali untuk mengukur gejala yang sama dan ternyata hasil pengukurannya relatif konsisten, maka alat pengukur tersebut dapat dikatakan reliabel.

\section{Teknik Analisa Data}

Pertimbangan mempergunakan analisis SEM PLS disebabkan karena alasan oleh adanya dimensi formatif yang membentuk variabel penelitian ini. Berdasarkan pilihan penggunaan SEM PLS tersebut, maka secara metodologi fokus studi SEM PLS adalah upaya untuk menganalisis dengan cermat karakter dimensi yang membentuknya atau merefleksikannya, melalui sejumlah uji instrument yaitu uji reability dan uji validity. Uji dilakukan terhadap variabel dan indikator penelitian secara menyeluruh. Prosedur pengujian instrument dinyatakan sebagai uji outer-model yang memanfaatkan analisis faktor untuk 
mendapatkan kelayakan atas variabel yang dipergunakan sebelum direlasikan menjadi hubungan kausal diantara variabel laten dependen dengan variabel laten independen pada suatu hubungan model struktural.

Langkah-langkah pengukuran dengan pendekatan SEM-PLS dilaksanakan dengan langkah-langkah sebagai berikut.

\section{Analisa model penelitian}

\section{a. Pengembangan model struktural}

Bilamana model struktural yang akan dianalisa termasuk model rekursif dan variabel latennya memiliki indikator yang bersifat formatif, refleksif, atau campuran. Pendekatan yang sesuai digunakan adalah $P L S$. Dalam pendekatan $P L S$, model struktural hubungan antar variabel laten disebut inner model. Model pengukuran (bersifat refleksif atau formatif) disebut outer model (Hair, et.al., 2012).

\section{b. Pengembangan diagram alur (path diagram)}

PLS merupakan model Structural Equation Modelling (SEM) dengan berbasis komponen atau varian. PLS menyerupai regresi akan tetapi lebih dari itu, PLS secara simultan menggabungkan model structural path (hubungan teoritis antar variabel laten) dan pada saat yang sama mengukur path tersebut. Dalam PLS, tidak semua bobot masingmasing indikator diasumsikan sama terhadap variabel laten. Indikator-indikator tersebut memiliki bobot yang beragam. Indikator dengan bobot yang lebih rendah akan berkontribusi rendah pula terhadap skor variabel laten (Chin, et.al., 1996).

c. Konversi diagram jalur ke sistem persamaan

\section{1) Structural (Inner) Model}

Inner model atau disebut juga structural model merupakan penjelasan hubungan antara variabel laten berdasarkan teori substantif.

\section{2) Measurement (Outer) Mode}

Outer model atau disebut juga dengan measurement model merupakan spesifikasi hubungan antara variabel laten dengan indikator atau variabel manifestnya, atau dengan kata lain mengukur seberapa jauh indikator tersebut dapat menjelaskan variabel latennya.

\section{d. Estimasi}

Henseler, et.al. (2009), menyatakan bahwa estimasi parameter yang berbasis kepada konsep SEM PLS dapat dikategorikan menjadi tiga, yaitu: 1) weight estimate; 2) path estimate; dan 3) means dan lokasi parameter.

Weight estimate berguna untuk menciptakan skor dari variabel laten. Path estimate (estimasi jalur) berguna untuk menghubungkan antar variabel laten dan menghubungkan variabel laten dengan blok indikatornya (loading). Means dan lokasi parameter dugunakan sebagai nilai konstanta regresi dari indikator dan variabel lain.

PLS menggunakan proses iterasi melalui tiga tahap dimana setiap tahapannya akan menghasilkan estimasi. Pada tahap pertama menghasilkan weight estimate. Pada tahap kedua menghasilkan inner model dan outer model. Sedangkan pada tahap ketiga menghasilkan means dan lokasi (konstanta).

Dalam tahapan pertama dan kedua, komponen skor estimasi bagi setiap variabel laten dapat digunakan 2 cara, dengan cara melalui outside approximation dan menggunakan inside approximation. Outside approximation menggambarkan weighted agregat dari indikator variabel, sedangkan inside aproksimasi menggunakan weighted agregat component score lain yang berhubungan dengan variabel dalam model teoritis. Tahap ketiga, dilaksanakan perhitungan mean setiap indikator dengan digunakannya data asli 
untuk mendapatkan parameter mean. Setelahnya dilakukan perhitungan means dari nilai weight pada variabel laten yang didapatkan pada tahap satu. Berdasarkan nilai mean untuk setiap variabel laten dan berdasarkan path estimate pada tahap dua, lokasi parameter bagi setiap variabel laten dependen dianaisis sebagai perbedaan antara mean yang baru dengan cara menghitung dengan systematic part accounted oleh pengaruh variabel laten.

\section{Evaluasi Goodness of Fit model SEM-PLS}

Terdiri dari Goodness of Fit outer model dan Goodness of Fit inner model.

a) Goodness of Fit outer model / uji model pengukuran

Covergent validity pada model pengukuran dengan refleksif indika-tor dinilai didasarkan atas korelasi antara item score atau component score dengan construct score dengan menggunakan PLS. Ukuran fefleksif individual disimpulkan tinggi jika terdapat rkorelasi lebih dari 0.70 dengan variabel yang ingin diukur. Tetapi untuk penelitian tahap awal berdasarkan pada pengembangan skala pengukuran, maka nilai loading 0,5 sampai 0,60 dianggap cukup (Chin, 1998).

Metode lain bagi penilainan discriminant validity melalui cara membandingkan nilai square root of average variance extracted (AVE) setiap variabel dengan korelasi antara variabel dengan variabel lainnya dalam model. Jika nilai akar kuadrat AVE setiap variabel lebih besar daripada nilai korelasi antara variabel dengan variabel lainnya dalam model, maka dikatakan memiliki nilai discriminant validity yang baik (Fornell dan Larcker, 1981).

\section{b) Structural (Inner) Model / Uji Model Struktural}

Evaluasi pada inner model dilaksanakan dengan melihat besarnya koefisien jalur strukturalnya. Nilai uji t statistiknya didapatkan dengan metode bootstrapping. Diperlukan juga memperhatikan $\mathrm{R}^{2}$ untuk variabel laten dependen. Nilai $\mathrm{R}^{2}$ sekitar 0,67 disimpulkan baik, 0,33 disimpulkan moderat, sedangkan 0,19 disimpulkan lemah. Sedangkan perubahan $\mathrm{R}^{2}$ dapat dipakai sebagai penilai pengaruh variabel laten tertentu terhadap variabel laten independen. Dapat dilaksanakan dengan menghitung $\mathrm{f} 2$. Apabila nilai $\mathrm{f} 2$ sama dengan 0,02 , 0,15 dan 0,35 dapat disimpulkan bahwa prediktor variabel laten memiliki pengaruh, kecil, menengah, atau besar terhadap model struktural.

Model Struktural dapat dianalisis dengan memakai $R$-squared $\left(\mathrm{R}^{2}\right)$ untuk variabel dependen, Stone-Geisser Q-squared test untuk predictive relevance. Juga uji t serta signifikansi dari koefisien parameter jalur struktural. Dalam penilainan model menggunakan PLS. dimulai dengan melihat $R$-squared untuk se-tiap variabel laten dependen. Cara untuk menginterpretasinya sama dengan interpretasi pada regresi. Perubahan nilai $R$-squared dapat dipakai untuk menentukan pengaruh variabel laten independen tertentu terhadap variabel laten dependen terkait pengaruh yang substantivenya.

\section{Hasil dan Pembahasan}

\section{Evaluasi Outer Model (Measurement Model)}

Pertimbangan mempergunakan analisis SEM PLS disebabkan karena alasan oleh adanya dimensi formatif yang membentuk variabel penelitian ini. Berdasarkan pilihan penggunaan SEM PLS tersebut, maka secara metodologi fokus studi SEM PLS adalah upaya untuk menganalisis dengan cermat karakter dimensi yang membentuknya atau merefleksikannya, melalui sejumlah uji instrument yaitu uji reliability dan uji validity terhadap variabel dan indikator yang diperoleh dari hasil penelitian. Prosedur pengujian instrument dinyatakan sebagai uji outer-model yang memanfaatkan analisis faktor untuk mendapatkan kelayakan atas variabel yang dipergunakan sebelum direlasikan menjadi hubungan kausal antara variabel laten dependen dengan variabel laten independen dalam suatu hubungan model structural.

Penelitian ini memanfaatkan metode analisis yang lebih lengkap dari sebelumnya, 
yaitu untuk mendapatkan internal consistency reliability, convergent reliability dan discriminant reliability (Ringle, et.al., 2012), dengan dukungan perangkat lunak SmartPls 3.2.3.

\section{Uji Reliabilitas Dimensi Reflektif}

Wong (2013) merekomendasikan penggunaan pengujian reliabilitas dengan mempergunakan loading indicator, dengan batas terendah sebesar 0,70, atau dapat lebih rendah setingkat dengan 0,60 untuk kegiatan penelitian bersifat ekploratif. Pengukuran reliability indicator dapat dilaksanakan berdasarkan metode composit reliability, di mana sebuah variabel dinyatakan reliabel apabila didapatkan composit reliability paling rendah sebesar 0,70. Pendekatan metode lainnya untuk mengukur reliabilitas sebuah variabel dapat dilaksanakan dengan metode cronbach's alpha (Cronbach, 1951), dengan menyatakan sebuah intrumen adalah reliabel dengan batas terendah cronbach's alpha adalah 0,70. Meskipun demikian, untuk penelitian eksploratif pada ilmu-ilmu sosial, cronbach's alpha dapat ditolerir dengan batas terendah 0,60 (Nunally dan Berstein, 1994), atau setingkat dengan nilai average variance extract (AVE) paling rendah sebesar 0,40 (Fornell dan Larcker, 1981).

Pengujian reliabilitas mempergunakan tiga metode alat ukur untuk mendapatkan informasi kelayakan instrumen penelitian berdasarkan hasil analisis perangkat lunak SmartPLS, seperti terlihat dalam Tabel 1.

Tabel 1

Uji Reliabilitas Variabel Penelitian

\begin{tabular}{cccccc}
\hline & $\begin{array}{c}\text { Nama } \\
\text { Variabel }\end{array}$ & CronbachAlpha & rho_A & C R & AVE \\
\hline X1 & $\begin{array}{c}\text { Penagihan Pajak } \\
\text { Kewajiban }\end{array}$ & 0,650 & 1,000 & & \\
X2 & Kepemilikan NPWP & & 0,650 & 0,774 & 0,408 \\
& Kesadaran Wajib & 0,697 & 0,876 & 0,769 & 0,463 \\
Y & Penerimaan Pajak & 0,613 & 0,669 & 0,748 & 0,341 \\
\hline
\end{tabular}

Berdasarkan Tabel 1, didapatkan untuk semua variabel sebaran nilai cronbach alpha diatas 0,60 dan terendah adalah 0,613 pada variabel penerimaan pajak (Y), kecuali penagihan pajak (X1) yang tidak memiliki nilai cronbach's alpha disebabkan memiliki dimensi formatif. Berdasarkan evaluasi sebaran nilai cronbach's alpha, maka dapat dinyatakan bahwa seluruh variabel bersumber dari instrument penelitian yang reliabel.

Konsep pengukuran berikutnya, adalah bersumber dari prosedur Dillon-Goldstein yang dikenal sebagai rho_A diperoleh dari perhitungan composite realibility berdasarkan prosedur Dillon-Goldstein rho_A (Wertz, et.al., 1974), yang menyatakan bahwa variabel dinyatakan reliabel apabila indeks rho_A diatas 0,60 dan dinyatakan sebuah variabel tidak reliabel apabila indeks rho_A berada dibawah 0,60. Berdasarkan Tabel 1 didapatkan sebaran nilai rho_A untuk seluruh variabel berada diatas 0,60 .

Berdasarkan uji composite reliability, didapatkan nilai AVE untuk kewajiban kepemilikan NPWP (X2) di atas nilai terendah 0,40 untuk nilai AVE yaitu sebesar 0,408. Begitu pula dengan nilai AVE dari variabel kesadaran wajib pajak mempunyai nilai sebaran diatas 0,40 sehingga dapat disimpulkan seluruh variabel reflektif dinyatakan memiliki instrument yang reliable.

\section{Uji Validitas Dimensi Reflektif}

Pengukuran berikutnya adalah melakukan pengujian terhadap validitas instrumen sebagai alat ukur untuk menetapkan kualitas instrument penelitian dalam rangka menghasilkan estimasi yang dapat dipercaya. Prosedur pengujian validitas instrument 
penelitian berdasarkan tiga metode pengukuran yaitu: a) penggunaaan metode AVE-crosscorrelation dari Fornell-Larscker (1981); b) penggunaan metode pengujian validitas berdasarkan cross-loading evaluation yang direkomendasikan oleh Henseler, et.al.(2009); dan c) pengujian validitas berdasarkan metode heterotrait-monotrait ratio (HMTR) dari Henseler, et.al, (2015).

\section{Metode AVE-Cross-Correlation}

Uji validitas berdasarkan prosedur Fornell-Larscker, dilaksanakan dengan membandingkan nilai AVE dari variabel bersangkutan dengan cross-correlation dari variabel bersangkutan terhadap variabel lainnya, yang dapat dibandingkan secara diagonal, sebagaimana terlihat dalam Tabel 2.

Tabel 2

Uji Validitas Discriminant Fornell-Larcker

\begin{tabular}{ccccc}
\hline & $\mathbf{X 1}$ & $\mathbf{X 2}$ & $\mathbf{X 3}$ & $\mathbf{Y}$ \\
\hline $\mathbf{X 1}$ & & & & \\
$\mathbf{X 2}$ & 0,483 & 0,638 & & \\
$\mathbf{X 3}$ & 0,442 & 0,374 & 0,680 & \\
$\mathbf{Y}$ & 0,428 & 0,535 & 0,552 & 0,583 \\
\hline
\end{tabular}

Variabel penagihan pajak (X1) tidak mempunyai nilai akar AVE karema variabel formatif. Variabel kewajiban kepemilikan NPWP (X2) dengan nilai akar AVE sebesar 0,638 yang dibandingkan secara diagonal dengan X1 adalah 0,483 serta dengan sebaran nilai korelasi dibawahnya yaitu 0,374 dan 0,535 yang ternyata seluruh korelasinya masih lebih rendah dibandingkan dengan nilai akar AVE dari X2, sehingga dapat dinyatakan bahwa variabel X2 adalah valid discriminant.

Variabel berikutnya adalah variabel kesadaran WP (X2) dengan nilai akar AVE adalah 0,680 yang ternyata masih lebih besar dari sebaran nilai korelasi yang tersebar disebelah kirinya serta sebaran korelasi X2 dengan variabel lainnya menyebar dibawah nilai akar AVE variabel X2 bersangkutan, sehingga dapat dinyatakan bahwa variabel X2 adalah valid discriminant. Evaluasi terhadap perbandingan akar AVE dengan sebaran cross-correlation secara diagonal dari variabel penerimaan pajak (Y) juga menunjukkan pola yang searah dengan variabel sebelumnya, sehingga dapat disimpulkan berdasarkan metode FornellLakcker bahwa instrumen penelitian seluruhnya adalah valid discriminant.

\section{Metode Cross-Loading Evaluation}

Penggunaan metode pengujian validitas berdasarkan cross-loading evaluation yang direkomendasikan oleh Henseler, et.al.(2009). Rekomendasi Chin, et.al. ( 2010) untuk mengukur discriminant validity dilaksanakan dengan metode cross-loading yaitu dengan membandingkan antara inner-correlation dari variabel yang bersangkutan dengan outercorrelation dari variabel yang bersangkutan terhadap cross-correlation dari variabelvariabel lainnya. Apabila sebaran nilai inner-correlation dari variabel bersangkutan lebih besar dari outer-correlation dari variabel bersangkutan terhadap variabel lainnya, maka variabel bersangkutan dinyatakan valid (Chin, 2010).

Berdasarkan Tabel 3 didapatkan hasil pengujian validitas instrument penelitian berdasarkan kerangka hubungan antara korelasi internal dari variabel bersangkutan dengan korelasi variabel tersebut dengan variabel lainnya. Korelasi internal variabel X1 adalah dengan X1.1, X1.2 sampai dengan X1.6 dinyatakan sebagai korelasi diri sendiri (innerloading), sedangkan sebaran korelasi variabel yang bersangkutan dengan pihak lain dinyatakan disebelah kanannya dari mulai dengan variabel $\mathrm{X} 2$ sampai dengan $\mathrm{Y}$, sebagaimana terlihat dalam Tabel 3 . 


\section{Tabel 3}

Uji Validitas Discriminant Cross-loading

\begin{tabular}{|c|c|c|c|c|}
\hline & $\mathrm{X} 1$ & $\mathrm{X} 2$ & $\mathrm{X} 3$ & $\mathrm{Y}$ \\
\hline $\mathrm{X} 1.1$ & 0,905 & 0,520 & 0,400 & 0,407 \\
\hline X1.2 & 0,409 & 0,370 & 0,181 & 0,377 \\
\hline X1.3 & $\mathbf{0 , 3 0 5}$ & 0,494 & 0,135 & 0,301 \\
\hline X1.4 & 0,624 & 0,406 & 0,276 & 0,371 \\
\hline X1.5 & 0,541 & 0,361 & 0,239 & 0,225 \\
\hline X1.6 & 0,486 & 0,279 & 0,215 & 0,337 \\
\hline $\mathrm{X} 2.1$ & 0,405 & 0,699 & 0,309 & 0,365 \\
\hline $\mathrm{X} 2.2$ & 0,195 & 0,638 & 0,255 & 0,478 \\
\hline $\mathrm{X} 2.3$ & 0,225 & 0,618 & 0,155 & 0,333 \\
\hline X2.4 & 0,257 & 0,581 & 0,165 & 0,193 \\
\hline X2.5 & 0,409 & 0,651 & 0,252 & 0,299 \\
\hline X3.1 & 0,097 & 0,040 & 0,674 & 0,286 \\
\hline X3.2 & 0,077 & 0,063 & 0,486 & 0,268 \\
\hline X 3.3 & 0,109 & 0,104 & 0,682 & 0,245 \\
\hline X3.4 & 0,546 & 0,474 & $\mathbf{0 , 8 3 3}$ & 0,535 \\
\hline Y1.1 & 0,150 & 0,279 & 0,278 & 0,485 \\
\hline Y1.2 & 0,185 & 0,208 & 0,191 & 0,441 \\
\hline Y1.3 & 0,263 & 0,362 & 0,283 & 0,666 \\
\hline Y1.4 & 0,426 & 0,345 & 0,519 & 0,784 \\
\hline Y1.5 & 0,142 & 0,332 & 0,300 & 0,498 \\
\hline Y1.6 & 0,230 & 0,381 & 0,209 & $\mathbf{0 , 5 5 6}$ \\
\hline
\end{tabular}

Berdasarkan uji validitas didapatkan inner-loading variabel penagihan pajak (X1) adalah valid, karena masih lebih besar dibandingkan dengan sebaran cross-correlation dari inner-loading X1 terhadap korelasinya dengan variabel X2, X3, dan Y, sehingga dinyatakan bahwa X1 adalah variabel yang valid discriminant. Evaluasi terhadap sejumlah innerloading dari masing-masing variabel terhadap cross-correlation dari variabel bersangkutan mendapatkan pola yang searah dengan variabel X1, sehingga dapat disimpukan bahwa berdasarkan pendekatan cross-loading, maka instrumen penelitian ini dinyatakan valid discriminant

\section{Metode Heterotrait-Monotrait Ratio}

Pengujian validitas berdasarkan metode heterotrait-monotrait ratio (HMTR) dari Henseler, et.al, (2015). Metode HMTR dilaksanakan dengan membandingkan antara innerloading dengan outer-loading dari variabel bersangkutan. The heterotrait-monotriat ratio of correlations (HMTR) dikembangkan oleh Henseler, et.al. (2015), yang menyatakan bahwa nilai HMTR sebarannya adalah lebih kecil dari 0,85 dan nilai confidence interval adalah lebih kecil dari 1,0, sehingga dapat dinyatakan variabel memiliki discriminant validity (Abugabah dan Sanzogni, 2010). Hasil dari metode HMTR, yang terlihat dalam Tabel 4.

Tabel 4

Uji Validitas DiscriminantHeterotrait-monotrait Ratio

\begin{tabular}{ccccc}
\hline & $\mathrm{X} 1.1$ & $\mathrm{X} 1.2$ & $\mathrm{X} 1.3$ & $\mathrm{Y} 1$ \\
\hline $\mathrm{X} 1.1$ & & & & \\
$\mathrm{X} 1.2$ & 0,431 & & & \\
$\mathrm{X} 1.3$ & 0,418 & 0,812 & & \\
$\mathrm{Y} 1$ & 0,204 & 0,388 & 0,547 & \\
\hline
\end{tabular}


Prosedur pengujian HMT ratio merupakan pola pendekatan konep korelasi internal dan eksternal dari variabel bersagkutan, diperbandingkan keduanya, sehingga kriteria maksimum dinyatakan valid adalah sebesar 0,85 , sedangkan sebaran diatas nilai 0,85 dinyatakan tidak valid. Berdasarkan pengujian, didapatkan seluruh hasil pengujian ( 6 hasil pengujian) didapatkan nilai yang lebih kecil dari 0,85. Maka dapat disimpulkan bahwa instrumen penelitian adalah valid. Dengan demikian, penelitian dapat ditingkatkan ke proses inner-model

\section{Pengujian Model Struktral (Inner Model)}

Pengujian hipotesis adalah tahap kedua setelah outer-model dapat memastikan bahwa instrumen penelitian adalah valid discriminant. Tahap kedua, adalah upaya evaluasi awal terhadap uji kelayakan model dengan menaganalisis kemampan model penelitian untuk menjelaskan variasi sebaran nilai pada variabel laten dependen yang dijelaskan oleh faktorfaktor yang mempengaruhinya. Untuk tujuan tersebut, pertama penelitian ini akan melihat sebaran nilai R2, kedua, akan dianalisis dengan mempergunakan metode predict relevance Stone-Geisser (Stone, 1974).

Hasil analisis R2 dan R2 adjusted terlihat pada Tabel 5, dimana terdapat 2 dependen variabel laten yang memiliki nilai $\mathrm{R} 2$.

Tabel 5

Sebaran Nilai R2 dan R2 adjusted

\begin{tabular}{ccc}
\hline & R Square & R Square Adjusted \\
\hline Kesadaran Wajib Pajak ( X3 ) & 0,229 & 0,213 \\
Penerimaan Pajak ( Y ) & 0,306 & 0,298 \\
\hline
\end{tabular}

Berdasarkan Tabel 5 didapatkan nilai R2 untuk penerimaan pajak (Y) sebesar 0,306 dan kesadaran wajib pajak (X3) sebesar 0,229. Hasil analisis ini membuktikan pembentukan variasi nilai yang diperoleh dari pengaruh variabel independen. Variasi nilai terbesar diperoleh dari prediksi penerimaan pajak (Y) sebesar 0,306 yang bersumber dari pengaruh variabel kesadaran WP (X3). Variabel kesadaran wajib pajak (X3) sebesar R2 $=0,229$ bersumber dari variasi pengaruh penagihan pajak (X1) dan variabel kewajiban kepemilikan NPWP (X2).

Berdasarkan evaluasi kelayakan model dari masing-,masing variabel laten dependen dengan faktor yang mempengaruhinya, didapatkan pola karakteristik yang sangat wajar dan searah dengan teori statistik yang tersedia, bahwa pada tingkat pengaruh dengan variabel yang lebih banyak didapatkan nilai R2 yang lebih besar (Hair,et.al., 2010). Hasil analisis R2 dan R2 adjusted membuktikan bahwa sebaran nilai dari R2 adjusted masih lebih rendah dibandingkan dengan sebaran nilai R2 pada setiap variabel sehingga disimpulkan bahwa perluasan model penelitian ini dimasa depan dengan menambahkan variabel baru sangat dimungkinkan.

Evaluasi kelayakan model penelitian diperlukan untuk mendapatkan gambaran kelayakan model secara menyeluruh. dilaksanakan berdasarkan prosedur Stone-Geisser (Stone, 1974; Geisser, 1974), yang dinyatakan sebagai predict relevance dinyatakan dalam bentuk formula $Q^{2}$.

$$
\begin{aligned}
& Q^{2}=1-\left[\left(1-R_{x 2}^{2}\right)\left(1-R_{y 1}^{2}\right)\right] \\
& Q^{2}=1-[(1-0,229)(1-0,306] \\
& Q^{2}=0,71
\end{aligned}
$$


Berdasarkan hasil perhitungan didapatkan $\mathrm{Q}^{2}=0,71$, sehingga dapat dinyatakan bahwa hanya sebesar 29 persen dari variasi nilai variabel laten dependen merupakan pengaruh faktor-faktor lain yang tidak diikutkan pada penelitian ini. Disimpulkan model penelitian sangat memadai untuk dilanjutkan ke tingkat pengujian hipotesis penelitian.

Penelitian ini juga membangun hipotesis penelitian dengan menelusuri peran mediasi yang dapat memberikan dampak peningkatan kualitas terhadap kinerja suksesi, sehingga menjadi relevan untuk diketahui pola karakteristik variabel penelitian yang memiliki peluang bagi terjadinya peran variabel tertentu sebagai mediator. Evaluasi terhadap kemungkinan terdapatnya peran mediasi dilaksanakan dengan mempergunakan metode evaluasi berdasarkan prosedur Cohen (1988) melalui prosedur effect size, yang dapat dipergunakan untuk melihat peluang terbentuknya sejumlah variabel berperan sebagai mediator (Kock, 2011).

Tabel 6 menyajikan hasil perhitungan effect size (Cohen, 1988), yang memberikan arah bagi terbentuknya variabel tertentu sebagai mediator. Berdasarkan Tabel 4.6 didapatkan nilai $\mathrm{f} 2$ untuk kesadaran WP lebih besar dari 0,35 sehingga tergolong strong effect untuk kesimpulan terdapatnya model full mediation. Hasil estimasi f2 untuk rerata menunjukkan nilai f2 lebih besar dari kriteria 0,10-0,35 menunjukkan bahwa pada model penelitian terdapat peran full mediation (Kock, 2011), sebagaimana terlihat dalam Tabel 6.

Tabel 6

Hasil Perhitungan Effect Size Cohen

\begin{tabular}{ccccc}
\hline & R Square & f_excludes & f_includes & f2 \\
\hline X3 & 0,229 & 0,306 & 0,05 & 0,44 \\
\hline
\end{tabular}

\section{Uji Hipotesis Penelitian}

Penelitian ini memiliki 5 (lima) tujuan penelitian, 2 (dua) diantaranya adalah hipotesis mediasi, yang perlu mendapat jawaban berdasarkan uji statistik SEM PLS yang akan dipergunakan untuk menjawab tujuan penelitian tersebut. Tujuan penelitian telah disusun dalam kerangka relasi antar variabel yang telah dipetakan berdasarkan rujukan teoritik yang tersedia, sehingga jawaban atas tujuan penelitian dapat diposisikan sebagai konfirmasi fenomena terhadap kerangka teoritik yang mendukung penelitian ini.

Tiga tujuan penelitian inti telah berhasil dilaksanakan pengujian disajikan pada Tabel 7 , sedangkan dua tujuan penelitian yang memuat peran mediasi disajikan pada Tabel 8 . Tiga tujuan penelitian yang merupakan uji pengaruh langsung antar variabel meliputi antara lain, a) pengaruh penagihan pajak terhadap kesadaran wajib pajak; b) pengaruh kewajiban kepemilikan NPWP terhadap kesadaran wajib pajak; dan c) pengaruh kesadaran wajib pajak terhadap penerimaan pajak.

Berdasarkan hasil analisis inner-model didapatkan seluruh tujuan penelitian berhasil dijawab. Penelitian ini mempergunakan nilai $t=1,96$ sebagai kriteria pengujian signifikansi, dengan pertimbangan bahwa nilai $t$ maksimal pada tabel $\mathrm{t}$ adalah $\mathrm{n}=120$, sebesar $\mathrm{t}=1.96$, dengan bootstrapping penelitian ini adalah sebesar $n=500$ untuk mendapatkan syarat didapatkan mediasi yang lebih robust (Nietze,et.al., 2012). Berdasarkan evaluasi penggunaan standar nilai $t$ tersebut, didapatkan seluruh tujuan penelitian memiliki nilai $t$ diatas 1,96, dengan p-values lebih kecil dari 5 persen, seperti terlihat dalam Tabel 7.

Tabel 7

Hasil Analisis Path dan Signifikansi Antar Relasi Variabel

\begin{tabular}{ccccccc}
\hline & $(\mathrm{O})$ & $(\mathrm{M})$ & $($ STDEV $)$ & O/STDEV & P Val. & Ket. \\
\hline X1 -> X3 & 0,341 & 0,369 & 0,131 & 2,605 & 0,000 & Support \\
X2 -> X3 & 0,209 & 0,227 & 0,101 & 2,072 & 0,039 & Support \\
X2 -> Y1 & 0,553 & 0,577 & 0,053 & 10,385 & 0,000 & Support \\
\hline
\end{tabular}


Berdasarkan hasil estimasi ketiga variabel independen yang memberikan pengaruh terhadap penerimaan pajak (Y) baik langsung maupun melalui mediator, ternyata kesadaran wajib pajak (X3) memberikan pengaruh terkuat dalam mempengaruhi penerimaan pajak (Y) yaitu sebesar 0,553, disusul oleh variabel independen penagihan pajak (X1) yang memberikan pengaruh sebesar 0,341 serta variabel independen kewajiban kepemilikan NPWP (X2) yang memberikan pengaruh sebesar 0,209 terhadap variabel kesadaran wajib pajak (X2), seperti terlihat dalam Gambar 2.

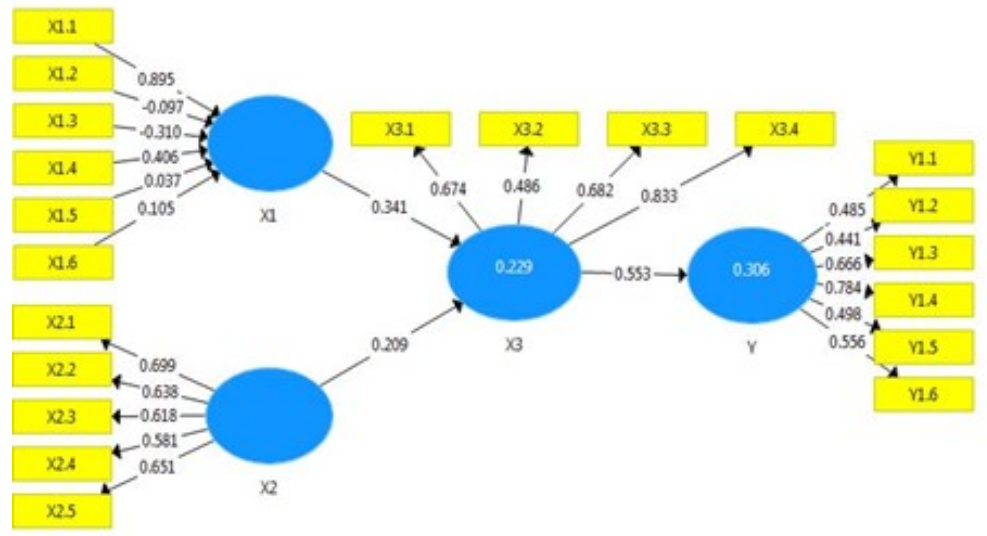

Gambar 2

Path Analysis dan Estimasi Relasi Antar Variabel

Berdasarkan hasil analisis effect size yang telah didapatkan sebelumnya, hasil analisis menunjukkan adanya Cohen effect size dengan $\mathrm{f} 2$ diatas 0,10 sehingga dimungkinkan dapat ditelusuri untuk meyakini adanya efek mediasi yang signifikan pada mediasi yang telah dirumuskan pada penelitian ini. Gambar 2 menyajikan informasi signifikansi path dan jalur mediasi penelitian yang mungkin didapatkan berdasarkan model mediasi Baron dan Kenny (1986), serta syarat terbentuknya mediasi berdasarkan alur signifikansi yang membentuk model full mediation atau partial mediation (Little, et.al., 2012).

Berdasarkan rumusan masalah dan tujuan penelitian, didapatkan 2 (dua), yang telah dirumuskan menjadi hipotesis yaitu relasi antara penagihan pajak (X1) dan kewajiban kepemilikan NPWP (X2) dengan penerimaan pajak (Y) yang di mediasi oleh kesadaran wajib pajak (X3), sebagaimana yang terlihat dalam Gambar 5.1.

Berdasarkan hasil analisis product indicator SmartPls 3, didapatkan mediasi yang terbukti signifikan, yaitu pengaruh secara tidak langsung dari variabel penagihan pajak (X1) terhadap variabel penerimaan pajak (Y) melalui peran mediasi variabel kesadaran wajib pajak (X3) dengan nilai t sebesar 2,514 yang ternyata masih lebih besar dari nilai standar nilai t sebesar 1,96. Didapatkan juga mediasi yang terbukti signifikan, yaitu pengaruh secara tidak langsung dari variabel kewajiban kepemilikan NPWP (X2) terhadap variabel penerimaan pajak (Y) melalui peran mediasi variabel kesadaran wajib pajak (X3) dengan nilai t sebesar 1, 965 yang ternyata masih lebih besar dari nilai standar nilai t sebesar 1,96, sebagaimana terlihat dalam Tabel 8.

Tabel 8

Hasil Analisis Indirect Effect Mediasi Variabel Penelitian

\begin{tabular}{cccccc}
\hline & $\begin{array}{c}\text { Original } \\
\text { Sample } \\
(\mathrm{O})\end{array}$ & $\begin{array}{c}\text { Sample } \\
\text { Mean (M) }\end{array}$ & $\begin{array}{c}\text { Standard Deviation } \\
(\text { STDEV })\end{array}$ & $\begin{array}{c}\text { T Statistics } \\
(\mid \mathrm{O} / \\
\text { STDEV } \mid)\end{array}$ & P Values \\
\hline $\mathrm{X} 1->\mathrm{Y}$ & 0,189 & 0,212 & 0,075 & 2,514 & 0,012 \\
$\mathrm{X} 2->\mathrm{Y}$ & 0,116 & 0,132 & 0,060 & 1,965 & 0,056 \\
\hline
\end{tabular}


Berdasarkan Tabel 8, terdapat komponen pembentuk mediasi yang signifikan, yaitu relasi antara variabel penagihan pajak (X1) dan kewajiban kepemilikan NPWP (X2) dengan penerimaan pajak (Y) yang di mediasi oleh kesadaran wajib pajak (X3), sehingga berdasarkan Hair et al (2010), pada jalur dimana direct effect itu signifikan, akan didapatkan bentuk partiall mediation. Pendekatan konsep mendiasi yang dilaksanakan penelitian ini tidak berbasis kepada prosedur perhitungan Sobel (1982), tetapi dengan model pengembangan analisis mediasi berdasarkan Zhao, et.al. (2010), serta aplikasi model mediasi berdasarkan SmartPls, maka proses mendapatkan uji signifikansi dilaksanakan melalui product indicator approach (Ringle, et.al., 2014), sehingga evaluasi posisi bentuk mediasi masih harus ditelusuri dengan memanfaatkan metode Variance Accounting For (VAF).

\section{Metode Variance Accounting For (VAF)}

Konsep Sobel (1982) sebagai prosedur perhitungan mediasi sudah dianggap ketinggalan konsep, apabila dikaitkan dengan pendekatan model SEM PLS yang berbasis kepada peranan indikator dalam membentuk hubungan antar relasi yang saling berkaitan satu sama lainnya Pendekatan model mediasi yang dipandang lebih relevan dengan model SEM PLS adalah model mediasi dengan pendekatan metode product indicator adalah model pendekatan yang lebih robust, disebabkan pada model Sobel tidak banyak diperhatikan pentingnya peranan indikator pada proses perhitungan mediasi, hal yang selalu menjadi fokus studi pada model SEM PLS (Hair, et.al., 2016).

Berdasarkan Gambar 2, didapatkan 2 (dua) bentuk partial mediation yaitu yaitu pengaruh secara tidak langsung dari variabel penagihan pajak (X1) terhadap variabel penerimaan pajak (Y) melalui peran mediasi variabel kesadaran wajib pajak (X3) dengan nilai $\mathrm{t}$ sebesar 2,514 dan pengaruh secara tidak langsung dari variabel kewajiban kepemilikan NPWP (X2) terhadap variabel penerimaan pajak (Y) melalui peran mediasi variabel kesadaran wajib pajak (X3) dengan nilai t sebesar 1, 965. Pendekatan metodologi terkini yang dapat dipergunakan dalam melakukan penilaian terhadap posisi mediasi dapat dilihat dengan melakukan evaluasi terhadap besaran effek yang diperankan dari indirect effect yang bersangkutan. Pengukuran atas peran mediasi dapat dilaksanakan melalui pendekatan variance accounting for (VAF) yang mengukur ratio nilai indirect effect terhadap total effect. Hair, et.al. (2013) menyatakan bahwa relasi mediasi dinyatakan sebagai partial mediation apabila VAF lebih kecil dari 50 persen dan dinyatakan sebagai full mediation apabila nilai VAF sama dengan atau lebih besar dari 50 persen, sebagaimana terlihat dalam Tabel 9.

Tabel 9

Hasil Analisis Mediasi Berdasarkan VAF

\begin{tabular}{cccccc}
\hline & $\begin{array}{c}\text { Direct } \\
\text { Effect }\end{array}$ & $\begin{array}{c}\text { Indirect } \\
\text { Effect }\end{array}$ & Total & $\begin{array}{c}\text { P } \\
\text { Values }\end{array}$ & VAF \\
\hline X1 $>$ Y & 0,341 & 0,189 & 0,530 & 0,012 & 0,470 \\
X2 - > Y & 0,209 & 0,116 & 0,325 & 0,056 & 0,675 \\
\hline
\end{tabular}

Berdasarkan hasil perhitungan VAF pada Tabel 9 didapatkan 2 (dua) mediasi, 1 (satu) diantaranya memiliki bentuk partial mediation yaitu model mediasi yang merelasikan variabel penagihan pajak (X1) dengan penerimaan pajak (Y) yang dimediasi oleh kesadaran wajib pajak (X3), dengan nilai VAF sebesar 0,470 yang lebih kecil dari 50 persen. Sedangkan 1 (satu) lainnya memiliki bentuk full mediation yaitu model mediasi yang merelasikan variabel kewajiban kepemilikan NPWP (X2) dengan penerimaan pajak (Y) yang dimediasi oleh kesadaran wajib pajak (X3), dengan nilai VAF sebesar 0,675 yang lebih besar dari 50 persen. Berdasarkan pendekatan VAF didapatkan kesimpulan yang searah. Dengan demikian, berdasarkan Ringle, et.al., 2014, didapatkan bukti empiris bahwa mediasi yang dihipotesiskan penelitian ini dapat dibuktikan (signifikan) berdasarkan uji 
statistik dengan tingkat kepercayaan 5 persen, bahwa berdasarkan metode VAF, didapatkan 1 (satu) bentuk partial mediation dan 1 (satu) bentuk full mediation.

\section{Hasil Penelitian}

\section{Pengaruh Langsung Penagihan Pajak Terhadap Kesadaran Wajib Pajak}

Analisis pengaruh penagihan pajak (X1) terhadap kesejahteraan (Y1) menunjukkan hubungan yang positif dan signifikan. Hipotesis nol diterima karena didapatkan nilai $\mathrm{t}$ sebesar 2,605 yang lebih besar dari nilai normal standard $t=1,96$ dengan $p$-value 0,009 , menunjukkan bahwa peran penagihan pajak (X1) secara langsung berpengaruh positif dan signifikan terhadap kesadaran wajib pajak (X3). Hasil penelitian ini membuktikan secara empiris bahwa tindakan-tindakan penagihan pajak (X1) secara langsung berpengaruh positif dan signifikan dalam menaikan kesadaran wajib pajak (X3) di KPP Pratama Gianyar.

\section{Pengaruh Langsung Kewajiban Kepemilikan NPWP Terhadap Kesadaran Wajib Pajak}

Analisis pengaruh kewajiban kepemilikan NPWP (X2) terhadap kesadaran wajib pajak (X3) menunjukkan hubungan yang positif dan signifikan. Hipotesis nol diterima karena didapatkan nilai $t$ sebesar 2,072 yang lebih besar dari nilai normal standard $t=1,96$ dengan taraf signifikansi 0,039, menunjukkan bahwa peran kewajiban kepemilikan NPWP (X2) secara langsung berpengaruh positif dan signifikan terhadap kesadaran wajib pajak (X3). Hasil penelitian ini membuktikan secara empiris bahwa kewajiban kepemilikan NPWP (X2) secara langsung berpengaruh positif dan signifikan dalam kesadaran wajib pajak (X3).

Hasil penelitian akan pengaruh langsung kewajiban kepemilikan NPWP (X2) dengan nilai $\mathrm{t}$ sebesar 2,072 terhadap kesadaran wajib pajak (X3) didapatkan lebih kecil dari pengaruh langsung penagihan pajak (X1) terhadap kesadaran wajib pajak (X3) dengan nilai $\mathrm{t}$ sebesar 2,605. Hal tersebut menunjukkan bahwa penagihan pajak (X1) mempunyai mempunyai pengaruh langsung yang lebih besar terhadap kesadaran wajib pajak (X3) dibandingkan kewajiban kepemilikan NPWP (X2).

\section{Pengaruh Langsung Kesadaran Wajib Pajak Terhadap Penerimaan Pajak}

Analisis pengaruh kesadaran wajib pajak (X3) terhadap penerimaan pajak (Y) menunjukkan hubungan yang positif dan signifikan. Hipotesis nol diterima karena didapatkan nilai t sebesar 10,385 yang lebih besar dari nilai normal standard $t=1,96$ dengan taraf signifikansi 0,000 , menunjukkan bahwa peran kesadaran wajib pajak (X3) secara langsung berpengaruh positif dan signifikan terhadap penerimaan pajak (Y). Hasil penelitian ini membuktikan secara empiris bahwa penerimaan pajak (Y) secara langsung akan dipengaruhi secara positif dan signifikan oleh kesadaran wajib pajak (X3) di KPP Pratama Gianyar

\section{Pengaruh Tidak Langsung Penagihan Pajak Terhadap Penerimaan Pajak Mediasi Kesadaran Wajib Pajak}

Tujuan penelitian ke empat adalah merumuskan pengaruh penagihan pajak (X1) terhadap penerimaan pajak (Y) melalui mediasi kesadaran wajib pajak (X3) yang berhasil dibuktikan penelitian ini. Relasi antara variabel penagihan pajak (X1) dengan variabel penerimaan pajak (Y) yang di mediasi oleh variabel kesadaran wajib pajak (X3) menghasilkan nilai uji statistik t sebesar 2,514 yang dinyatakan lebih besar dari nilai standar $\mathrm{t}=1,96$. Hal tersebut menunjukkan bahwa relasi mediasi kesadaran wajib pajak (X3) adalah signifikan berdasarkan taraf signifikansi 0,012. Kesadaran wajib pajak (X3) sebagai pemediasi dinyatakan sebagai partial mediation, karena pengaruh penagihan pajak (X1) terhadap penerimaan pajak (Y) terbukti positif dan signifikan, serta diperkuat oleh analisis VAF dengan nilai VAF sebesar 0,470 atau lebih kecil dari 50 persen mendapatkan 1 (satu) bentuk partial mediation (Ringle, et.al., 2014). 
Pengaruh Tidak Langsung Kewajiban Kepemilikan NPWP Terhadap Penerimaan Pajak Mediasi Kesadaran Wajib Pajak

Tujuan penelitian ke lima adalah merumuskan pengaruh kewajiban kepemilikan NPWP (X2) terhadap penerimaan pajak (Y) melalui mediasi kesadaran wajib pajak (X3) yang berhasil dibuktikan penelitian ini. Relasi antara variabel kewajiban kepemilikan NPWP (X2) dengan variabel penerimaan pajak (Y) yang di mediasi oleh variabel kesadaran wajib pajak (X3) menghasilkan nilai uji statistik t sebesar 1,965 yang dinyatakan lebih besar dari nilai standar $\mathrm{t}=1,96$. Hal tersebut menunjukkan bahwa relasi mediasi kesadaran wajib pajak (X3) adalah signifikan berdasarkan taraf signifikansi 0,056.

Kesadaran wajib pajak (X3) sebagai pemediasi dinyatakan sebagai full mediation, karena pengaruh kewajiban kepemilikan NPWP (X2) terhadap penerimaan pajak (Y) terbukti positif dan signifikan, serta diperkuat oleh analisis VAF dengan nilai VAF sebesar 0,675 atau lebih besar dari 50 persen mendapatkan 1 (satu) bentuk full mediation (Ringle, et.al., 2014).

\section{Simpulan}

Dari hasil penelitian dan pembahasan, dapat disimpulkan sebagai berikut: 1) Penagihan pajak secara langsung berpengaruh positif dan signifikan terhadap kesadaran wajib pajak. Hasil penelitian ini membuktikan secara empiris bahwa tindakan-tindakan penagihan pajak secara langsung berpengaruh positif dan signifikan dalam menaikan penerimaan pajak di KPP Pratama Gianyar. 2 ) Kewajiban kepemilikan NPWP secara langsung berpengaruh positif dan signifikan terhadap kesadaran wajib pajak. Hasil ini membuktikan secara empiris bahwa kewajiban kepemilikan NPWP secara langsung berpengaruh positif dan signifikan dalam kesadaran wajib pajak di KPP Pratama Gianyar. 3) Kesadaran WP secara langsung berpengaruh positif dan signifikan terhadap penerimaan pajak. Hasil ini membuktikan secara empiris bahwa penerimaan pajak secara langsung akan dipengaruhi secara positif dan signifikan oleh kesadaran WP di KPP Pratama Gianyar. 4) Dengan dimediasi Kesadaran WP, pengaruh penagihan pajak terhadap penerimaan pajak terbukti positif dan signifikan. Hasil ini membuktikan secara empiris bahwa berdasarkan analisis VAF didapatkan 1 (satu) bentuk partial mediation. 5) Dengan dimediasi kesadaran WP, pengaruh kewajiban kepemilikan NPWP terhadap penerimaan pajak terbukti positif dan signifikan. Hasil ini membuktikan secara empiris bahwa berdasarkan analisis VAF didapatkan 1 (satu) bentuk full mediation.

\section{Daftar Pustaka}

Anastasya, D. dan Lilis S. (2009). Perpajakan Indonesia. Yogyakarta:Andi

Atarwaman, R. J. D. (2020). Pengaruh Kepemilikan NPWP, Pemeriksaan Pajak, Peneriman Pajak, Dan Kesadaran Wajib Pajak Terhadap Penerimaan Pajak. Journal Akuntansi, Vol.6 No.2, Universitas Pattimura Jayapura, Oktober 2020.

Chin, W. W., dan T. Frye, (1996).PLS Graph, Soft Modelling Inc., Calgary.

Chin, W. W. (1998). The Partial Least Squares Approach To Structural Equation Modeling, dalam G. A. Marcoulides (Ed.), Modern Methods For Business Research. NewYork: Mahwah, Lawrence Erlbaum.

Fornell, C., dan D.F. Larcker, (1981).Evaluating Structural Equation Models with Unobservable Variables and Measurement Error, Journal of Marketing Research Vol.18(1).

Ginting, R. (2006). Pengaruh Pemberian Surat Penagihan terhadap Pembayaran Tunggakan Pajak Penghasilan. Jurnal Ekonomi \& Bisnis, Vol.5, No.1, Maret 2006.

Hair, J.F., W.C. Black, B.J. Babin, dan R.E.Anderson, (2010).Multivariate Data Analysis, 7th edition, PearsonPrenticeHall, New York. 
Hair, J.F., M. Sarstedt, C.M. Ringle, dan J.A. Mena, (2012). An Assessment Of The Use Of Partial Least Squares Structural Equation Modeling In Marketing Research, Journal of the Academy of Marketing Science Vol.40(3).

Henseler, Jörg, Christian M. Ringle, dan Sinkovics, Rudolf R., (2009). The Use Of Partial Least Squares Path Modeling In International Marketing, Journal Advances in International Marketing Vol.20.

Henseler, J., C.M. Ringle, dan M. Sarstedt, (2015), A New Criterion For Assessing Discriminant Validity in Variance-Based Structural Equation Modeling, Journal of the Academy of Marketing Science, Vol. 43 No. 1.

Hidayat, W. dan A. A. Nugroho. (2010). Studi Empiris Theory of Planned Behavior dan Pengaruh Kewajiban Moral pada Perilaku Ketidakpatuhan Pajak Wajib Pajak Orang Pribadi. Jurnal Akuntansi Dan Keuangan, Vol. 12, No. 2, Universitas Airlangga, November 2010.

Jatmiko, A. N. (2006). Pengaruh Sikap Wajib Pajak pada Pelaksanaan Sanksi Denda, Pelayanan Fiskus, dan Kesadaran Perpajakan Terhadap Kepatuhan Wajib Pajak. Tesis. Program Studi Magister Akuntansi Universitas Diponegoro Semarang.

Kock, Ned, (2011). Using WarpPLS in e-collaboration studies: Mediating effects, control and second order variables, and algorithm choices, International Journal e-Collaboration Vol. 7.

Mantra, I. B. (2001). Langkah-Langkah Penelitian Survei, Edisi III. Yogyakarta: BPFG-UGM.

Mardiasmo. (2011). Perpajakan. Edisi Revisi. Yogyakarta. Andi.

Mustikasari, E. (2007). Kepatuhan Wajib Pajak Badan di Perusahaan Industri Pengolahan di Surabaya. Makalah Simposium Nasional Akuntansi X. Surabaya.

Rahayu, S. K. (2010). Perpajakan Indonesia (Konsep dan Aspek Sosial), Cetakan Pertama. Yogyakarta: Graha Ilmu.

Ringle, Christian M., Sarstedt, Marko, Schlittgen, Rainer, (2014).Genetic Algorithm Segmentation in Partial Least Squares Structural Equation Modeling, Journal OR Spectrum Vol. 36(1).

Robbins, S.P, dan Judge. (2008). Perilaku Organisasi, Buku 2, Jakarta : Salemba Empat.

Stone, M., (1974). Cross Validatory Choice and A ssessment of Statistical Predictions, Journal of the Royal Statistical Society Vol. 36(2).

Suandy, E. (2008). Perencanaan Pajak. Jakarta: Salemba Empat.

Sugiyono. (2011). Metode Penelitian Kuantitatif, Kualitatif, dan $R \& D$, Bandung: Alfabeta.

Sugiyono. (2016). Metode Penelitian Bisnis, Cetakan ke-13, Bandung: Alfabeta.

Tansuria, B. I. (2010). Pokok-Pokok Ketentuan Umum Perpajakan, Edisi Pertama. Yoyakarta: Graha Ilmu.

Werts, C.E., R.L. Linn, dan K.G. Jöreskog, (1974). Interclass Reliability Estimates: Testing Structural Assumptions, Journal Educational and Psychological Measurement Vol.34.

Wong, K. K., (2013). Partial Least Squares Structural Equation Modeling (PLS-SEM) Techniques Using SmartPLS, Marketing Bulletin Vol. 24, Technical Note 1 